\title{
The $k f r A$ gene is the first in a tricistronic operon required for survival of IncP-1 plasmid R751
}

\author{
Correspondence \\ Grazyna Jagura-Burdzy \\ gjburdzy@poczta.ibb.waw.pl
}

Received 5 September 2005

Revised 9 January 2006

Accepted 6 February 2006

\author{
Malgorzata Adamczyk, ${ }^{1,2}$ Patrycja Dolowy, ${ }^{1}$ Michal Jonczyk, ${ }^{1}$ \\ Christopher M. Thomas ${ }^{3}$ and Grazyna Jagura-Burdzy ${ }^{1}$ \\ ${ }^{1}$ The Institute of Biochemistry and Biophysics, Polish Academy of Sciences (PAS), 02-106 \\ Warsaw, Pawinskiego 5A, Poland \\ ${ }^{2}$ Central Institute of Labour Protection, National Research Institute, 00-701 Warsaw, \\ Czerniakowska 16, Poland
}

${ }^{3}$ School of Biosciences, University of Birmingham, Edgbaston, Birmingham B15 2TT, UK

\section{INTRODUCTION}

Sequencing of bacterial genomes has revealed not only that some chromosomes are very similar to megaplasmids in their replication and stable inheritance mechanisms, but also that most standard oriC-based chromosomes carry a range of stable inheritance functions, already studied in some detail on bacterial plasmids (Gerdes et al., 2000a). This includes active partitioning systems of the par $A B$ family (Gerdes et al., 2000b; Bignell \& Thomas, 2001), multimer resolution systems of the $x e r C / D$ family (Summers \& Sherratt, 1984; Blakely et al., 1993) and a variety of postsegregational killing systems (Gerdes et al., 2000a; Zielenkiewicz \& Ceglowski, 2001). Thus, studies on bacterial plasmids, particularly large, low-copy-number plasmids, can be of direct relevance for understanding key events of the bacterial cell cycle. Genomic approaches also reveal genes that are conserved between many systems and cluster with known replication and stable inheritance functions,

Abbreviations: DAPI, 4',6-diamidino-2-phenylindole; PAS, Polish Academy of Sciences; WT, wild-type; YTH system, yeast two-hybrid system.

The DNA sequence and predicted amino acid sequence of the R751 region containing kfrA-upf54.8 and the $5^{\prime}$ end of upf54.4 are available as supplementary data with the online version of this paper. but do not yet have a role assigned. One such gene family has as its archetype the $k f r A$ gene of IncP- $1 \alpha$ plasmid RK2 that we studied many years ago, but for which we did not establish a phenotype, although we speculated that it may be involved in active partitioning (Jagura-Burdzy \& Thomas, 1992; Williams \& Thomas, 1992). $\mathrm{Kfr}_{\mathrm{RK} 2}$ is 308 aa in length, is a site-specific DNA binding protein, and is predicted to be almost $100 \% \alpha$-helical, which is consistent with its circular dichroism (CD) spectrum (Jagura-Burdzy \& Thomas, 1992). It is predicted to consist of an N-terminal, globular, DNA binding domain and an extended coiled-coil tail. Database searching revealed similarity to proteins of the myosin/ kinesin family and, recently, to prokaryotic structural maintenace of chromosomes (SMC) and MukB-like proteins (Hirano, 1998; Soppa, 2001). However, there is no easily identified nucleotide-binding site in $\mathrm{KfrA}$, so it seems unlikely to be able to provide the force-generating element of a molecular motor.

Recent accumulation of plasmid sequences has revealed other members of the $k f r A$ family, located in or close to a cluster of stable inheritance functions. In both pFBAOT6 (Rhodes et al., 2004) and pIP02 (Tauch et al., 2002), this gene is close to stable inheritance functions very similar 
to the active partitioning/central control region of RK2 (Pansegrau et al., 1994; Thorsted et al., 1998). In other plasmids, the $k f r A$ orthologue is clustered with replication functions (pMOL98, GenBank accession no. AJ 345055; pSa, Close \& Kado, 1992), with partitioning functions (pXAC33, accession no. NC 003921; pKDSC50, accession no. NC 002638; Haneda et al., 2001), or a mixture of replication and stable inheritance determinants (pRA2, accession no. NC 005909; Kwong et al., 1998, 2000; pO157, accession no. NC 002128; Burland et al., 1998). This prompted us to reexamine the IncP-1 plasmids to see if we could establish a role for this gene in stable inheritance. The IncP-1 plasmids are, so far, the only system in which the operons encoding parA $($ inc $C)$ and parB (korB) homologues and the associated parS sequences (Motallebi-Veshareh et al., 1990; Williams et al., 1998) have been shown to require additional plasmid functions for full effectiveness (Thorsted et al., 1998). Thus, in both RK2 and R751, the central control region (consisting of central control operon (cco) korAincCkorB and orphan $k f r A$, upf54.8 and upf54.4 genes; Fig. 1) provides a significant partitioning phenotype, but this is increased markedly by the addition of the klc and kle regions, and it has been shown that the effect of these regions depends on an intact central control region (Thorsted et al., 1998). It is possible that the $k f r A$ operon provides an independent stable inheritance mechanism or that it enhances that activity of another mechanism. This forms the basis for trying to establish what role, if any, the genes flanking the central control operon play in IncP-1 plasmid stability.

The stability of RK2 (IncP-1 $\alpha$ ) relies on active partitioning (Motallebi-Veshareh et al., 1990; Williams et al., 1998), assisted by kle and klc functions whose role is not understood (Macartney et al., 1997). It also encodes a multimer resolution system (parABC) (Roberts \& Helinski, 1992; Easter et al., 1998) and a post-segregational killing system (parDE) (Easter et al., 1998; Roberts et al., 1993; Johnson et al., 1996). R751 (IncP-1 $\beta$ ) lacks the whole parABCDE region. Thus, the stable inheritance of R751 is based only on the presence of the central control region, assisted by a more basic set of klc and kle operons (Thorsted et al., 1998). Its kle region is shorter than in RK2, because it does not contain the kleCD genes. On the other hand, the klc operon of R751 has a functional $k l c A$ gene which is inactivated in RK2 by Tn 1 insertion (Pansegrau et al., 1994). Therefore, it seems likely that the central control region of R751 provides the basis for the definition of the minimal requirements for this region; the central control operon codes only for $\operatorname{kor} A$, incC and $\operatorname{kor} B$, and not for the two genes $\operatorname{korF}$ and $\operatorname{kor} G$ that are present in IncP- $1 \alpha$. The $u p f 54.4$ ORF is also $50 \%$ shorter, encoding a protein lacking the N-terminal 231 aa, as compared with RK2. Despite these differences, R751 is even more stably maintained than RK2, at least in Escherichia coli and Pseudomonas species, so we have chosen R751 as a simpler model than RK2 to analyse the role of the orphan genes $k f r A$, upf54.8 and upf54.4.

Comparison between DNA and amino acid sequences of R751 and RK2 in this region (Fig. 1) showed low conservation in the $k f r A$ ORFs (50\% DNA identity, $38 \%$ amino acid identity) but high conservation in the upf54.8 and upf54.4 of both representatives (70\% DNA identity, 68 and $64 \%$ amino acid identity, respectively). Despite this unusually low conservation of the primary sequences of $\mathrm{KfrA}_{\mathrm{RK} 2}$ and $\mathrm{KfrA}_{\mathrm{R} 751}$, both proteins are highly $\alpha$-helical and have an almost identical predicted secondary structure, with an N-terminal globular part and a long, coiled-coil $\alpha$-helical tail (Jagura-Burdzy \& Thomas, 1992; data not shown for $\left.\mathrm{Kfr}_{\mathrm{R} 751}\right)$. The only function identified so far for the whole region $\left(k f r A\right.$, upf54.8, upf54.4) is for $\mathrm{KfrA}_{\mathrm{RK} 2}$ and concerns the autoregulation of transcription from $k f r A p$ (Jagura-Burdzy \& Thomas, 1992). The previous study of $\mathrm{KfrA}_{\mathrm{RK} 2}$ by Williams et al. (1998) showed that an internal in-frame deletion of $k f r A$, in a pOG04 derivative (hybrid replicon P7-pMB1 with stabilization functions of the central control region of RK2), did not affect the stability of the plasmid when it had a low copy-number in a polA1 strain. Although RNA polymerase binding sites have been identified in the upf54.8 and upf54.4 region of RP4 (=RK2) by electron microscopy (Pansegrau et al., 1994), DNA sequence analysis of both RP4 and R751 in this region has failed to identify strong candidate promoters, raising the possibility

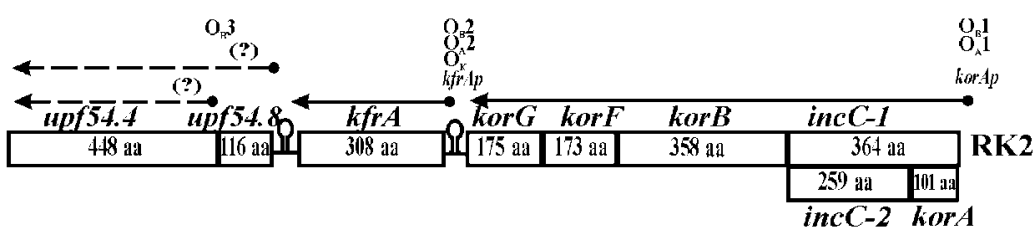

\begin{tabular}{|lllllll|}
\hline 70 & 72 & 50 & Identity DNA (\%) & 77 & 72 & 79 \\
64 & 68 & 38 & Identity aa (\%) & 78 & 60 & 79 \\
\hline
\end{tabular}

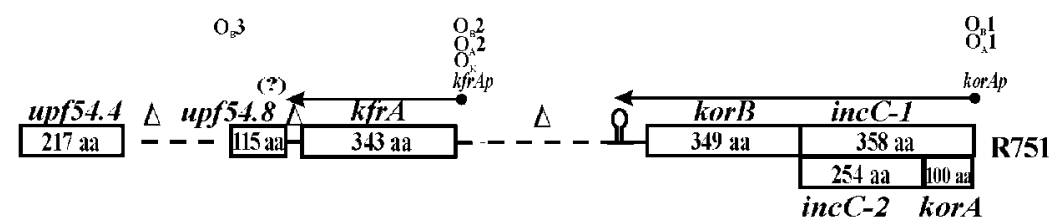

Fig. 1. Genetic organization of the studied region of R751. Comparison of the central control regions of RK2 (IncP-1 $\alpha$ ) and R751 $($ IncP-1 $\beta)$. ORFs are boxed, transcripts are indicated by arrows and broken lines, terminators are shown by the hairpin-loop symbol, and promoters for korA and $k f r A$ are indicated as well as the binding sites for $\operatorname{KorA}\left(\mathrm{O}_{\mathrm{A}}\right)$, KorB $\left(\mathrm{O}_{\mathrm{B}}\right)$ and $\mathrm{KfrA}\left(\mathrm{O}_{\mathrm{K}}\right)$. The numbers in the central box show the level of DNA sequence identity between the corresponding genes from RK2 and R751 and predicted amino acid sequences of their products. A question mark in parentheses signifies a lack of data about operon organization before we started our analysis. 
that all these genes constitute an operon expressed from the $k f r A$ promoter. On the other hand, the sequence of a putative Rho-independent terminator, previously identified in RP4 between $k f r A$ and upf54.8 (Pansegrau et al., 1994), is conserved in R751 (Supplementary data). In order to define better what role, if any, $k f r A$, upf54.8 and upf54.4 play in the stable inheritance of R751, we have addressed a number of questions in this paper. Do the three ORFs belong to the same operon and how is the expression of the operon regulated in R751? Can the genes in this region be inactivated and what effect will the mutations have on R751 biology? What is the function of the unusual $\alpha$-helical KfrA and, possibly, the other two proteins? Do KfrA, Upf54.8 and Upf54.4 interact with each other to fulfil their biological function?

\section{METHODS}

Bacterial strains and growth conditions. E. coli strains used were K12 strains DH5 $\alpha \mathrm{F}^{-}$(Ф80dlacZLM15) recA1 endA1 gyrA96 thi-1 hsdR17 $\left(r_{\mathrm{k}}{ }^{-} m_{\mathrm{k}}{ }^{+}\right)$supE44 relA1 deoR $\triangle($ lacZYA-argF)U196, C600K thr-1 leu-6 thi-1 lacY1 supE44 ton21 galK (McKenney et al., 1981), NEM259 met, $\operatorname{trpR}$, supE, supF, $h s d R^{-}$(W. Brammar, University of Leicester, UK), E. coli B strain BL21 $\mathrm{F}^{-}$ompt hsdS $S_{\mathrm{B}}\left(\mathrm{r}_{\mathrm{B}}{ }^{-} \mathrm{m}_{\mathrm{B}}{ }^{-}\right) \mathrm{gal}$ dcm ( $\lambda$ DE3) (Novagen), and E. coli $\mathrm{C}$ strains C2110 polA1 his rha (D. R. Helinski, University of California, San Diego, CA, USA) and $\mathrm{C}^{2} 110 \mathrm{Rif}^{\mathrm{R}}$ (this work). Bacteria were generally grown in L broth (Kahn et al., 1979) at $37^{\circ} \mathrm{C}$. Some experiments were performed at 25 or $42{ }^{\circ} \mathrm{C}$. L agar (L broth with $1.5 \%, \mathrm{w} / \mathrm{v}$, agar) was supplemented with antibiotics as appropriate: benzylpenicillin sodium salt ( $150 \mu \mathrm{g} \mathrm{ml}^{-1}$ in liquid media and $300 \mu \mathrm{g} \mathrm{ml}^{-1}$ in agar plates) for penicillin resistance; kanamycin sulphate $\left(50 \mu \mathrm{g} \mathrm{ml}^{-1}\right)$ for kanamycin resistance; tetracycline hydrochloride $\left(10-25 \mu \mathrm{g} \mathrm{ml}{ }^{-1}\right)$ for tetracycline resistance; and streptomycin sulphate $\left(30 \mu \mathrm{g} \mathrm{ml}^{-1}\right)$ for streptomycin resistance. Rifampicin was used at $25 \mu \mathrm{g} \mathrm{ml}^{-1}$. The $\mathrm{L}$ agar used for blue/white screening contained $0 \cdot 1 \mathrm{mM}$ IPTG and $\mathrm{X}-\mathrm{Gal}$ at $40 \mu \mathrm{g} \mathrm{ml}^{-1}$.

Yeast strains and growth conditions. Saccharomyces cerevisiae strain L40 MAT a, trp1, leu2, his3, ade2, LYS2::lexA-HIS3, URA3:: lexA-lacZ was used for transformation (Clontech) (Fields \& Song, 1989). Yeast cells were grown in YPD medium (1\% yeast extract, $2 \%$ Bacto peptone and $2 \%$ glucose). Plasmid-containing yeast strains were grown in YNB medium $(0 \cdot 67 \%$, yeast nitrogen base and $3 \%$, glucose) supplemented with a mixture of appropriate nutrients lacking tryptophan (for selection of pBTM116 derivatives), leucine (for selection of pGAD424 derivatives) or both as required (for selection of double transformants). Agar was added to a concentration of $2 \%(\mathrm{w} / \mathrm{v})$ for the plates. To grow transformants for the $\beta$-galactosidase filter-lift assay, YNB agar was supplemented with $0.5 \%$ instead of $3 \%(\mathrm{w} / \mathrm{v})$ glucose. For the $\beta$-galactosidase assay using liquid cultures, the yeast cells were grown to exponential phase in YNB medium with $0.5 \%(\mathrm{w} / \mathrm{v})$ glucose and then transferred to YNB medium with $3 \%(\mathrm{w} / \mathrm{v})$ ethanol for several hours. For testing the expression of the His reporter gene in strain L40, YNB plates were supplemented with a mixture of amino acids (Clontech) lacking tryptophan, leucine and histidine. Plates were incubated at $30^{\circ} \mathrm{C}$ for $3-4$ days.

Plasmids. The plasmids used in this study are listed in Table 1.

For expression of cloned ORFs, we used the high-copy-number $\mathrm{Pn}^{\mathrm{R}}$ vector pGBT30 (Jagura-Burdzy et al., 1991), based on the pMB1 replicon with $\operatorname{lacl}^{\mathrm{Q}}$ and tacp separated from $\lambda t_{\mathrm{R} 1}$ by the multiple cloning site of pUC18 (Fig. 2C). A PstI-SalI fragment of pGBT30 derivatives, with the ORF of interest and all upstream control elements, was recloned into a broad-host-range $S \mathrm{mr}^{\mathrm{R}}$ IncQ-based replicon, pGBT400 (Jagura-Burdzy et al., 1999b), or $\mathrm{Tc}^{\mathrm{R}}$ broad-host-range pBBR1MCS-3 (Kovach et al., 1995). Sequencing of the initial PCR product corresponding to $k f r A_{\mathrm{R} 751}$ revealed an extra codon ACC (an extra Thr at amino acid position 246) (supplementary data) relative to the published sequence, but none of the studies performed here suggested that this was a mutant that had lost any activity. We sequenced two other independently amplified $k f r A$ ORF clones and an identical change was found. It may be that the difference was due to an error in the original sequencing. The internal $k f r A$ deletion $(\Delta \alpha k f r A)$ was created by removal of an internal NotI fragment encoding 70 aa between A136 and A207. C- and N-terminal kfrA deletions were obtained using the unique NotI restriction site in pMAB424.11, a pGAD424 derivative with $\Delta \alpha k f r A$. The NotI linearized plasmid was treated with a DNA PolI Klenow fragment and then ligated either with an oligonucleotide carrying an SalI site and stop codons in all three frames (next section), to create $\triangle C k f r A$, or with an oligonucleotide carrying an EcoRI recognition site, followed by an ATG codon in-frame with the rest of $\mathrm{KfrA}$, to create $\triangle N k f r A$. EcoRI digestion and religation removed the N-terminal part of $k f r A$. All constructions were checked by sequencing of the new junction point.

A plasmid for KfrA purification was constructed by inserting the $k f r A$ allele into a derivative of pET28a $\mathrm{Km}^{\mathrm{R}}$ (Studier \& Moffatt, 1981; Novagen), modified with the help of the synthetic oligomer, so that a $\mathrm{His}_{6}$-tag and thrombin cleavage site preceded, almost directly, the EcoRI site (Lukaszewicz et al., 2002). Purified His-tagged KfrA was N-

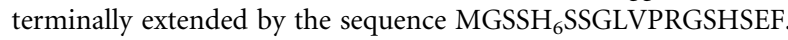

E. coli-S.cerevisiae shuttle plasmids used in the yeast two-hybrid (YTH) system, based on vectors pBTM116 (Invitrogen) and pGAD424 (Fields \& Song, 1989; Ma \& Ptashne, 1987; Clontech Matchmaker), fused the polypeptides encoded by EcoRI-SalI inserts to the $\mathrm{C}$ terminus of the LexA binding domain (BD) and GAL4 activation domain (AD), respectively. The system provided $\mathrm{Ap}^{\mathrm{R}}$ selection in E. coli and $\mathrm{LEU}^{+}$ (pGAD424) or $\mathrm{TRP}^{+}$(pBTM116) selection in the yeast cells.

Plasmid DNA isolation, analysis, cloning and manipulation. Plasmid DNA was isolated by standard procedures (Birnboim \& Doly, 1979). Digestion of plasmid DNA with restriction enzymes was carried out under conditions recommended by suppliers, and digested DNA was run on $0 \cdot 8-2 \%(\mathrm{w} / \mathrm{v})$ agarose gels. Standard PCR reactions (Mullis et al., 1986) were performed as described by JaguraBurdzy \& Thomas (1994), with the pairs of primers listed in Table 2.

The PCR reaction to amplify the ORF for $k f r A$ was performed with a hot start denaturation step $\left(98^{\circ} \mathrm{C}\right.$ for $\left.5 \mathrm{~min}\right)$ and 35 cycles of denaturation $\left(94{ }^{\circ} \mathrm{C}\right.$ for $\left.30 \mathrm{~s}\right)$, annealing $\left(52{ }^{\circ} \mathrm{C}\right.$ for $\left.30 \mathrm{~s}\right)$ and elongation $\left(72{ }^{\circ} \mathrm{C}\right.$ for $90 \mathrm{~s})$. The reaction ended with a final elongation step $\left(72^{\circ} \mathrm{C}\right.$ for $7 \mathrm{~min}$ ). The PCR reaction mixture was supplemented with $\mathrm{N}, \mathrm{N}$ dimethylformamide to a final concentration of $2 \%(\mathrm{v} / \mathrm{v})$.

PCR products were usually cloned into the pGEM-T vector (Promega) and later recloned as EcoRI-SalI fragments into appropriate vectors. All PCR-derived clones were analysed by DNA sequencing to check their fidelity.

Sequencing and computer sequence analysis. DNA sequencing was performed using an Applied Biosystems 377 automated DNA sequencer (Alta Bioscience, School of Biochemistry, University of Birmingham, UK) or a Pharmacia ALF automatic sequencer (IBB, PAS) using dye terminator kits supplied by the manufacturer. DNA and amino acid sequence analysis was carried out using the GCG Wisconsin Package version 8.0. Sequences were compared to GenBank/EMBL databases and studied using the programs BLASTN and BLASTP (NCBI), BLAST (Swiss server) and Coil tool (ExPASy). 
Table 1. Plasmids used in this study

\begin{tabular}{|c|c|c|}
\hline Designation & Relevant features & References \\
\hline pAKE600 & ori $_{\mathrm{MBI}}$, ori $T_{\mathrm{RK} 2}, \mathrm{Ap}^{\mathrm{R}}, s a c B$ & El-Sayed et al. (2001) \\
\hline pBBR1MCS-3 & Broad-host-range cloning vector, $\mathrm{Tet}^{\mathrm{R}}$ & Kovach et al. (1995) \\
\hline pBTM116 & $\begin{array}{l}\text { Shuttle vector } E \text {. coli/S. cerevisiae, ori } i_{\mathrm{MBI}} / 2 \mu \text {, } \\
\mathrm{Ap}^{\mathrm{R}} / \operatorname{trp} 1, \mathrm{LexA}_{\mathrm{BD}}\end{array}$ & Invitrogen \\
\hline pET28a & ori $_{\mathrm{MBI}}, \mathrm{Km}^{\mathrm{R}}, \mathrm{T} 7 \mathrm{p}$, lacO, His tag, T7 tag & Novagen \\
\hline pET28mod & ori $_{\mathrm{MBI}}, \mathrm{Km}^{\mathrm{R}}$, T7p, lacO, His tag & G. Jagura-Burdzy \\
\hline pGAD424 & $\begin{array}{l}\text { Shuttle vector } E \text {. coli/S. cerevisiae, ori } \mathrm{ColEl}_{1} / 2 \mu \text {, } \\
\mathrm{Ap}^{\mathrm{R}} / \text { leu2, GAL4 } 4_{\mathrm{AD}}\end{array}$ & Fields \& Song (1989) \\
\hline pGBT30 & ori $_{\mathrm{MBI}}, \mathrm{Ap}^{\mathrm{R}}$, lacI ${ }^{\mathrm{Q}}$, tacp expression vector & Jagura-Burdzy et al. (1991) \\
\hline pGBT314 & pGAD424 derivative, $\mathrm{GAL}_{\mathrm{AD}}-i n c C 2_{\mathrm{R} 751}$ & G. Jagura-Burdzy \\
\hline pGBT400 & ori $_{\text {IncQ }}, \mathrm{Sm}^{\mathrm{R}}$, lacl $I^{\mathrm{Q}}$, tacp expression vector & Lukaszewicz et al. (2002) \\
\hline pGBT401 & ori $_{\mathrm{IncQ}}, \mathrm{Sm}^{\mathrm{R}}$, lacI $I^{\mathrm{Q}}$, tacp $-k o r A_{\mathrm{RK} 2}$ & Jagura-Burdzy et al. (1999b) \\
\hline pGEM-T & $\operatorname{ori}_{\mathrm{MBI}}, \mathrm{Ap}^{\mathrm{R}}$ & Promega \\
\hline pРT01 & ori $_{\mathrm{SC} 101}, \mathrm{Km}^{\mathrm{R}}$, promoterless $x y l E$ & Macartney et al. (1997) \\
\hline $\mathrm{pR} 751 \mathrm{Tet}^{\mathrm{R}}$ & IncP- $1 \beta$, Tet $^{\mathrm{R}}$ cassette from RK2 & Thorsted et al. (1998) \\
\hline pUC18 & ori $_{\mathrm{MBI}}, \mathrm{Ap}^{\mathrm{R}}$ & Yanisch-Perron et al. (1985) \\
\hline pWS131 & ori $_{\mathrm{MBI}}, \mathrm{Ap}^{\mathrm{R}}$, lacl $I^{\mathrm{Q}}$, tacp- $-k f r A_{\mathrm{RK} 2}$ & Thomas et al. (1990) \\
\hline pKK38 & ori $_{\mathrm{MBI}}, \mathrm{Ap}^{\mathrm{R}}$, lacl $\mathrm{Q}^{\mathrm{Q}}$, tacp-kor $A_{\mathrm{R} 751}$ & Kostelidou \& Thomas (2002) \\
\hline \multirow{2}{*}{\multicolumn{3}{|c|}{$\begin{array}{l}\text { Plasmids constructed during this work } \\
\text { pUC18 derivative }\end{array}$}} \\
\hline & & \\
\hline $\mathrm{pUC7/8}$ & $\begin{array}{l}k f r A \text { promoter amplified with primers \#7 } \\
\text { and \#8, inserted in SmaI }\end{array}$ & \\
\hline \multicolumn{3}{|c|}{ pGBT30 derivatives (expression vector) } \\
\hline pMAB30.1 & $\begin{array}{l}k f r A_{\mathrm{R} 751} \text { amplified with primers } \# 9 \text { and } \# 10 \text {, } \\
\text { inserted as EcoRI-SalI fragment }\end{array}$ & \\
\hline pMAB30.11 & $\begin{array}{l}\Delta \alpha k f r A \text { allele (NotI internal } 210 \text { bp fragment } \\
\text { removed), inserted as above }\end{array}$ & \\
\hline pMAB30.12 & $\begin{array}{l}\Delta C k f r A \text { allele encoding } \mathrm{N} \text {-terminal } 136 \text { aa of } \\
\text { KfrA (N-KfrA), inserted as above }\end{array}$ & \\
\hline pMAB30.13 & $\begin{array}{l}\Delta N k f r A \text { allele encoding C-terminal } 136 \text { aa of } \\
\text { KfrA (C-KfrA), inserted as above }\end{array}$ & \\
\hline pMAB30.2 & $\begin{array}{l}\text { kor } B_{\mathrm{R} 751} \text { amplified with primers \#11 and \#12, } \\
\text { inserted as above }\end{array}$ & \\
\hline pMAB30.3 & $\begin{array}{l}\text { incC1 } 1_{\mathrm{R} 751} \text { amplified with primers \#13 and \#14, } \\
\text { inserted as above }\end{array}$ & \\
\hline pMAB30.4 & $\begin{array}{l}\text { upf54. } 8_{\mathrm{R} 751} \text { amplified with primers \#3 and \#4, } \\
\text { inserted as above }\end{array}$ & \\
\hline pMAB30.5 & $\begin{array}{l}\text { upf54.4 } 4_{\mathrm{R} 751} \text { amplified with primers \#5 and \#6, } \\
\text { inserted as above }\end{array}$ & \\
\hline pPDB30.6 & $\begin{array}{l}\text { kor } A \text { kor } B_{\mathrm{R} 751} \text { fragment amplified with primers } \\
\# 20 \text { and \#11, inserted as above }\end{array}$ & \\
\hline pPDB30.14 & $\begin{array}{l}\Delta C_{2} k f r A \text { allele encoding C-terminal KfrA } \Delta 187- \\
323, \text { inserted as above }\end{array}$ & \\
\hline \multicolumn{3}{|c|}{ pGBT400 derivatives (expression vector) } \\
\hline pMAB40.1 & $\begin{array}{l}\text { PstI-SalI fragment of pMAB30.1 carrying lacI } \\
\text { tacp- } k f r A_{\mathrm{R} 751}\end{array}$ & \\
\hline pMAB40.2 & $\begin{array}{l}\text { PstI-SalI fragment of pMAB30.2 carrying lacI } \\
\text { tacp-kor }_{\mathrm{R} 751}\end{array}$ & \\
\hline \multicolumn{3}{|c|}{ pBBR1MCS-3 derivative (expression vector) } \\
\hline pPDB3.6 & $\begin{array}{l}\text { PstI fragment of pPDB30.6 carrying lacl } \mathrm{Q}^{\mathrm{Q}} \\
\text { tacp-korAkorB } B_{\mathrm{R} 751}\end{array}$ & \\
\hline \multicolumn{3}{|c|}{ pET28mod derivative (protein overexpression) } \\
\hline pMAB28.1 & EcoRI-SalI fragment of pMAB30.1 & \\
\hline
\end{tabular}


Table 1. cont.

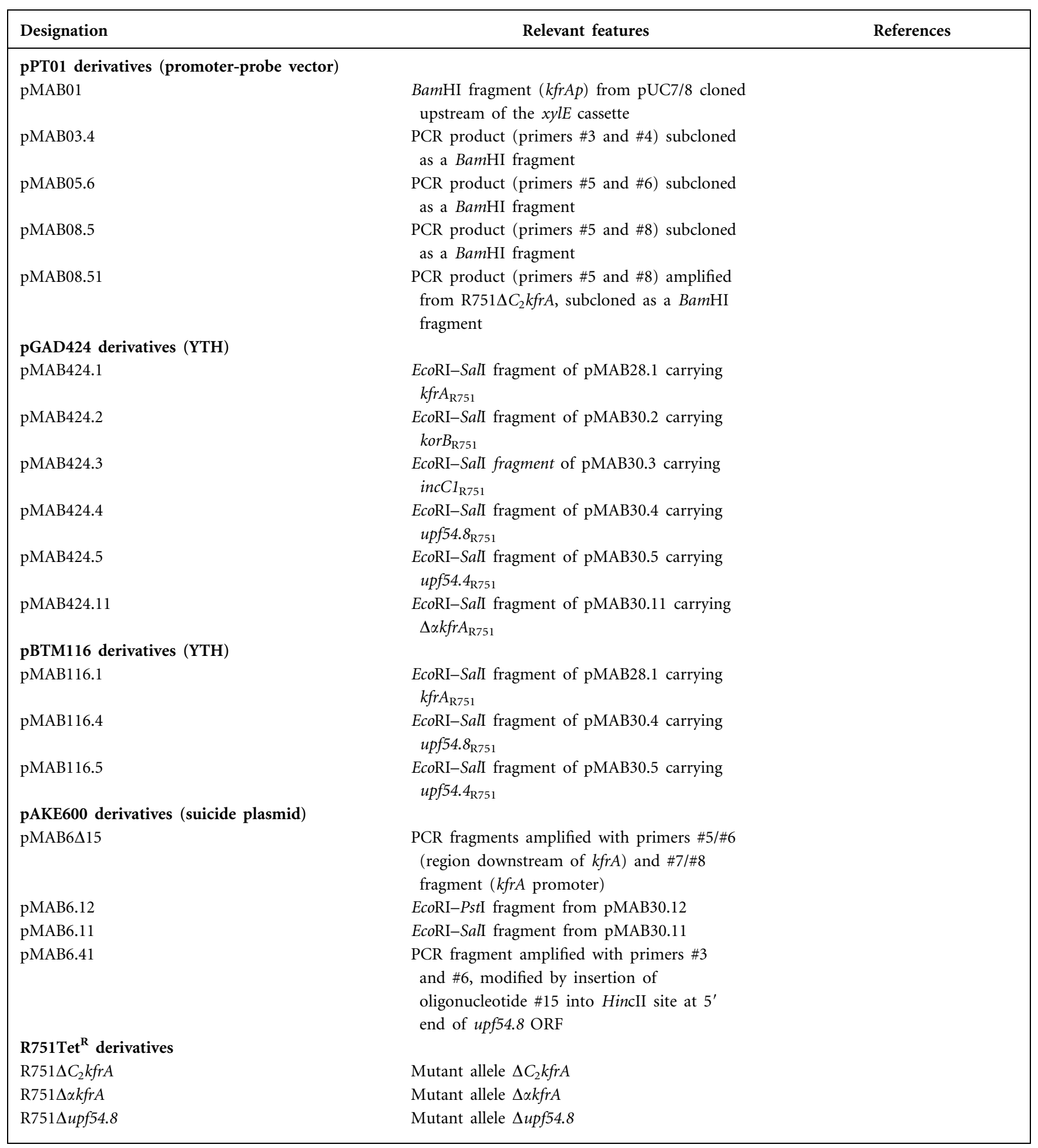

E. coli transformation and PCR-mediated screening of transformants. Competent cells of $E$. coli were prepared by the standard $\mathrm{CaCl}_{2}$ method (Sambrook et al., 1989). To screen for the recombinant plasmids, each transformant colony picked from the selective plate was resuspended in $200 \mu \mathrm{l}$ water and boiled for $2 \mathrm{~min}$. After centrifugation, 5-10 $\mu$ l supernatant (depending on the plasmid copy number) was added to a $25 \mu \mathrm{l}$ PCR reaction mixture. Alternatively, bacterial colonies were directly transferred into $25 \mu$ PCR reaction mixture supplemented with $0 \cdot 5 \mu \mathrm{l}, \mathrm{N}$-dimethylformamide.

Bacterial conjugation. Overnight cultures of the donor and recipient strain were grown in selective medium. One millilitre of each 
culture was drawn into a syringe mounted on a Millipore filter. The bacterial suspensions were filtered through a sterile nitrocellulose membrane, which was then placed face-up onto an $\mathrm{L}$ agar plate and incubated at $37^{\circ} \mathrm{C}$ overnight. The filter was transferred to a tube containing $1 \mathrm{ml} \mathrm{L}$ broth and vortexed to resuspend the bacteria. Serial dilutions of the suspension were plated out on $\mathrm{L}$ agar with appropriate selection and allowed to grow for $48 \mathrm{~h}$ at $37^{\circ} \mathrm{C}$.

Yeast transformation. Yeast transformation was performed using the PEG/LiAc standard method (Chen et al., 1992). Either single or double transformations were conducted and transformants selected and stored on minimal YNB agar.

Determination of LacZ activity in yeasts. $\beta$-Galactosidase activity was monitored by the filter-lift assay with X-Gal as a substrate and by the quantitative liquid culture assay (Clontech) using ONPG as substrate. The protein concentration was estimated using the Bradford assay (Bradford, 1976). The specific activity of $\beta$-galactosidase activity was expressed in standard units where one unit represents the amount of enzyme that hydrolyses $1 \mathrm{nmol}$ ONPG (mg protein) ${ }^{-1} \min ^{-1}$ at $30^{\circ} \mathrm{C}$.

Determination of catechol 2,3-oxygenase activity (XyIE) in bacteria. Catechol 2,3-oxygenase activity (the product of $x y l E$ ) was assayed in exponentially growing bacteria (Zukowski et al., 1983) and normalized to the same plasmid level as the control. One unit of catechol 2,3-oxygenase is defined as the amount needed to convert $1 \mu \mathrm{M}$ catechol in $1 \mathrm{~min}$ under standard conditions. Protein concentration was determined using the Bradford method (Bradford, 1976).

Purification of $\mathbf{H i s}_{\mathbf{6}}$-tailed KfrA. Exponentially growing E. coli BL21(2DE3)(pMAB28.1) was induced with $0.5 \mathrm{mM}$ IPTG at a cell density of $\sim 2 \times 10^{8}$ c.f.u. $\mathrm{ml}^{-1}$ and grown for an additional $2-3 \mathrm{~h}$ with shaking at $37^{\circ} \mathrm{C}$ (Arnold, 1991). The cells from $300 \mathrm{ml}$ culture were harvested by centrifugation and sonicated. The cell lysate/ $\mathrm{Ni}^{2+}$-nitrilotriacetic acid/agarose mixture was stirred for $60 \mathrm{~min}$ at $42^{\circ} \mathrm{C}$ and then transferred to a column. The purification procedure of $\mathrm{His}_{6}$-tailed KfrA was monitored by SDS-PAGE using a Pharmacia Phast gel system.

Preparation of anti-KfrA antiserum. Purified $\mathrm{His}_{6}-\mathrm{KfrA}$ protein $\left(1 \mathrm{mg} \mathrm{ml}^{-1}\right)$ was injected into a rabbit. The blood collected from the rabbit was allowed to clot at room temperature before removing the antiserum. Anti-KfrA antibodies were affinity-purified on $\mathrm{His}_{6}-$ KfrA bound to Affi-gel 15 (Bio-Rad), using a method described by Reznekov et al. (1996) with modifications introduced by Bignell et al. (1999). The antibodies were stored at $-20^{\circ} \mathrm{C}$ in $50 \%(\mathrm{v} / \mathrm{v})$ glycerol.

Estimation of KfrA concentration in the cells carrying R751Tet ${ }^{R}$ by Western blotting. Growth of E. coli NEM259(R751Tet $\left.{ }^{\mathrm{R}}\right)$ was monitored by $\mathrm{OD}_{600}$. The culture was diluted and plated on $\mathrm{L}$ agar to establish c.f.u. $\mathrm{ml}^{-1}$. Bacteria were harvested from an appropriate volume depending on the phase of growth to collect similar numbers of cells. The cells were washed in water and resuspended in $200 \mu \mathrm{l}$ sonication buffer ( $50 \mathrm{mM}$ phosphate buffer, $\mathrm{pH} 8 \cdot 0,300 \mathrm{mM}$ $\mathrm{NaCl}$ ). Bacteria were kept on ice and disrupted by sonication in short bursts for $2 \mathrm{~min}$. Crude extracts were cleared by centrifugation at $4{ }^{\circ} \mathrm{C}$ in a microfuge for $15 \mathrm{~min}$ at $12000 \mathrm{~g}$. Protein concentration was measured using the Bradford method (Bradford, 1976). Proteins from the cleared extracts were separated on $12.5 \%(\mathrm{w} / \mathrm{v})$ SDSPAGE gels (Laemmli, 1970) and electroblotted (semi-dry transfer unit) for $1-2 \mathrm{~h}$ onto nitrocellulose membranes (Protron; Schleicher \& Schuell). Probing of the blots was carried out using the amplified alkaline phosphatase goat anti-rabbit immunoblot assay (Promega) with anti-KfrA antiserum at a dilution of $1: 100000$ as the primary antibody. The cell extracts were compared to a range of concentrations of purified $\mathrm{His}_{6}-\mathrm{KfrA}$ on the same gel. Band intensity on Western blots was determined using Image Quant (Molecular Dynamics).
Immunofluorescence microscopy. The fixation and permeabilization of cells and subsequent staining for immunofluorescence were carried out as described by Bignell et al. (1999). Ten microlitres of affinity-purified anti-KfrA and anti-KorB antibodies were used as the primary antibodies $(1: 5000$ dilution for anti-KfrA and $1: 2000$ dilution for anti-KorB antibodies in $2 \%$, w/v, BSA/PBS) followed by $10 \mu \mathrm{l}$ anti-rabbit IgG FITC-conjugate solution $\left(6 \cdot 9 \mu \mathrm{g} \mathrm{ml}^{-1}\right.$ in $2 \%$, $\mathrm{w} / \mathrm{v}, \mathrm{BSA} / \mathrm{PBS}$ ) (Sigma). The coverslip was placed onto a microscope slide in a solution of $4^{\prime}$,6-diamidino-2-phenylindole (DAPI)/Vectorshield mounting medium (Vector Laboratories) (ratio of $1: 4$ DAPI $1 \mu \mathrm{g} \mathrm{ml}^{-1}$ to Vectorshield). Cells were studied with an Olympus IX70 inverted reflected light fluorescence microscope fitted with a Sensys charge-coupled device (CCD) camera (Photometrics). Images were captured and manipulated on a Macintosh G3 with the Smartcapture I program (Digital Scientific).

Introduction of mutant alleles into R751Tet $^{R}$ backbone by reverse genetics. E. coli strain NEM259(R751Tet $\left.{ }^{\mathrm{R}}\right)$ was transformed with suicide vector pAKE600 derivatives (El-Sayed et al., 2001). Double transformants were conjugated with the recipient strain C2110Rif ${ }^{\mathrm{R}}$ in which the suicide vector based on pMBI ori was unable to replicate. Putative conjugants with R751Tet ${ }^{\mathrm{R}}$-suicide vector cointegrated plasmids were selected on L agar with rifampicin, penicillin and tetracycline. After double restreaking, $\mathrm{Rif}^{\mathrm{R}} \mathrm{Pen}^{\mathrm{R}} \mathrm{Tet}^{\mathrm{R}}$ colonies were used to inoculate $\mathrm{L}$ broth containing $10 \%(\mathrm{w} / \mathrm{v})$ sucrose and tetracycline to facilitate the removal of the suicide vector insertion from R751Tet ${ }^{\mathrm{R}}$. Survivors were plated on L agar with $10 \%$ $(\mathrm{w} / \mathrm{v})$ sucrose and tetracycline and checked for the Pen ${ }^{\mathrm{S}}$ phenotype. Suc $^{\mathrm{R}} \mathrm{Tet}^{\mathrm{R}} \mathrm{Pen}^{\mathrm{S}}$ colonies were analysed by colony PCR to determine whether allele exchange had occurred and, where necessary, the PCR products were gel-purified and digested with SalI $(\Delta C k f r A, \Delta u p f 54.8)$. To confirm the knockout of the $k f r A$ gene in the R751Tet ${ }^{\mathrm{R}}$ backbone protein, extracts were analysed by Western blotting with anti-KfrA antibodies.

Determination of plasmid stability. Plasmid stability tests were performed as described by Williams et al. (1998) and Macartney et al. (1997). E. coli strain NEM259 was transformed with plasmid $\mathrm{R}_{751 \mathrm{Tet}}{ }^{\mathrm{R}}$ (or its derivatives) and transformants were selected on $\mathrm{L}$ agar plates containing tetracycline. The transformants were grown in selective medium and then diluted $10^{5}$-fold into non-selective $\mathrm{L}$ broth. Samples of the culture were collected every $12 \mathrm{~h}$ (at which point the cultures were diluted $10^{5}$-fold and transferred into fresh medium), diluted and plated out onto $\mathrm{L}$ agar and then transferred onto L agar with tetracycline. The c.f.u. were counted to determine the proportion of bacteria retaining the plasmid.

RT-PCR reactions. One microgram of total RNA (isolated by Qiagen RNeasy kit), suspended in diethyl pyrocarbonate-treated water, was mixed with $2.5 \mathrm{pM}$ gene-specific downstream primer \#1 annealing to the $3^{\prime}$ end of $u p f 54.4$, and the reverse transcriptase reaction was performed with $200 \mathrm{U}$ SuperScript RT. RNA was removed by treatment with RNase and cDNA was purified using GlassMAX spin cartridges as recommended by the manufacturer (GibcoBRL). Purified cDNA was used as a template for PCR with primer pairs as in Fig. 2(B, C).

\section{RESULTS}

\section{kfrA, upf54.8 and upf54.4 constitute a transcriptional unit}

From the original studies on IncP- $1 \alpha$ plasmid RK2 it appears that the $k f r A$ gene forms an autogenously regulated, monocistronic operon, leaving completely open the benefit that it may provide for RK2 (Thomas et al., 1990). However, there 
Table 2. Primers for PCR reactions

Restriction enzyme recognition sites are underlined and start/stop codons are in bold type.

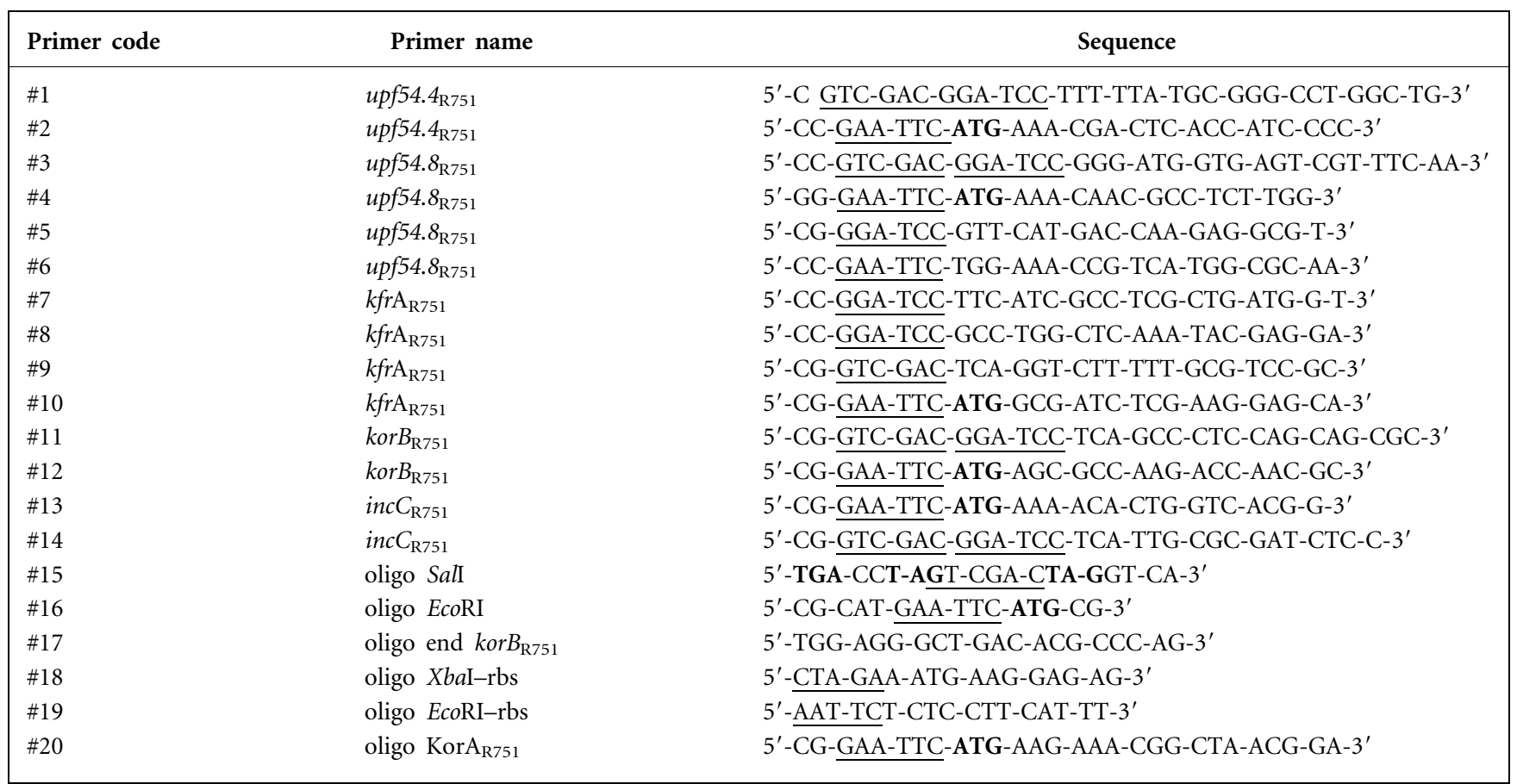

are no experimental data confirming termination of transcription after $k f r A$ or independent transcription of downstream genes upf54T.8 and upf54.4. To test the possibility that all three genes form a single operon (and may have a common function), reporter gene fusions were first constructed with $x y l E$ and subsegments of this region (Fig. 2A and supplementary data for primer positions). Strong transcriptional activity was detected for the region containing the predicted $k f r A p$ (pMAB01; nucleotides 2201-2597, supplementary data), whereas activity was only very weak for a fragment spanning the end of $k f r A$ and the start of upf54T.8 (pMAB03.4; nucleotides 3666-4062) and hardly detectable for another fragment running from upf54.8 to upf54.4 (pMAB05.6; nucleotides 3432-3691). When the cloned segment started upstream of $k f r A$ and ended within upf54.8 (pMAB08.5; nucleotides 2201-3691), much higher transcriptional activity was observed compared to the upf54.8 fragment alone (pMAB03.4), indicating that transcription originating within, or upstream of, $k f r A$ was responsible for most of the upf54.8 transcription. To further locate this activity, a $408 \mathrm{bp}$ internal deletion in $\mathrm{kfr} A$ was created, running from nucleotides 3025 to 3432 (pMAB08.51). This resulted in a further fourfold increase in transcription into upf54.8, confirming that the promoter responsible for upf54.8 transcription must be upstream of nucleotide 3025 , close to the beginning of $k f r A$ at nucleotide 2467 (Supplementary data). Although this deletion did not abolish KfrA autorepressor activity (see below), the increase in XylE activity in pMAB08.51 versus pMAB08.5 suggests that the promoter activity measured was under the control of KfrA. No obvious promoters, other than $k f r A p$, were found in the remaining R751 DNA present in pMAB08.51, and also no similarities to the putative KfrA binding site identified in $k f r A p$. Therefore, the simplest explanation is that transcription from $k f r A p$ ran through into upf54.8. This may have added to the weak promoter activity detected in the intergenic region between $k f r A$ and upf54.8.

Independent evidence for co-transcription of $k f r A, u p f 54.8$ and upf54.4 came from isolation of total RNA from strain NEM259(R751Tet ${ }^{\mathrm{R}}$ ) and PCR on cDNA obtained with reverse transcriptase and primer \#1 (supplementary data) complementary to the $3^{\prime}$ end of upf54.4. PCR products of expected sizes were obtained with primer pairs spanning both the upf54.4-upf54.8 and upf54.8-kfrA junctions, as well as for the whole of $k f r A$, indicating that the cDNA, and hence mRNA, covered the whole region (Fig. 2A, B). As a negative control, we performed RT-PCR on the korB-kfrA intergenic region, which contained a predicted strong transcriptional terminator preceding $k f r A p$ (primers $7 / 17$ ) and on the $k f r A$ promoter region (primers $7 / 8$ ), and obtained no products. All these primer pairs amplified the appropriate fragments from the R751 DNA template in parallel PCR reactions. We therefore conclude that while upf54.8 and upf54.4 may have been weakly expressed independently of $k f r A p$, the majority of their transcription was part of a tricistronic unit starting with $k f r A$.

\section{Regulation of transcription from kfrAp}

The DNA sequence of $k f r A p_{\mathrm{R} 751}$ contains highly conserved sequences, known to bind the global regulators of IncP-1 


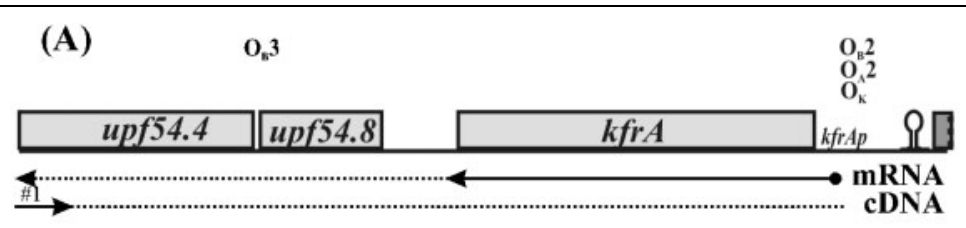

\section{Promoter-probe plasmids}

\section{Promoter}

activity

(XylE)(U)
RT-PCR

$\begin{array}{ll}4.0 & - \\ 0.01 & + \\ 0.004 & + \\ 0.06 & \text { ND } \\ 0.24 & \text { ND } \\ \text { ND } & + \\ \text { ND } & - \\ \text { ND } & +\end{array}$

(B)

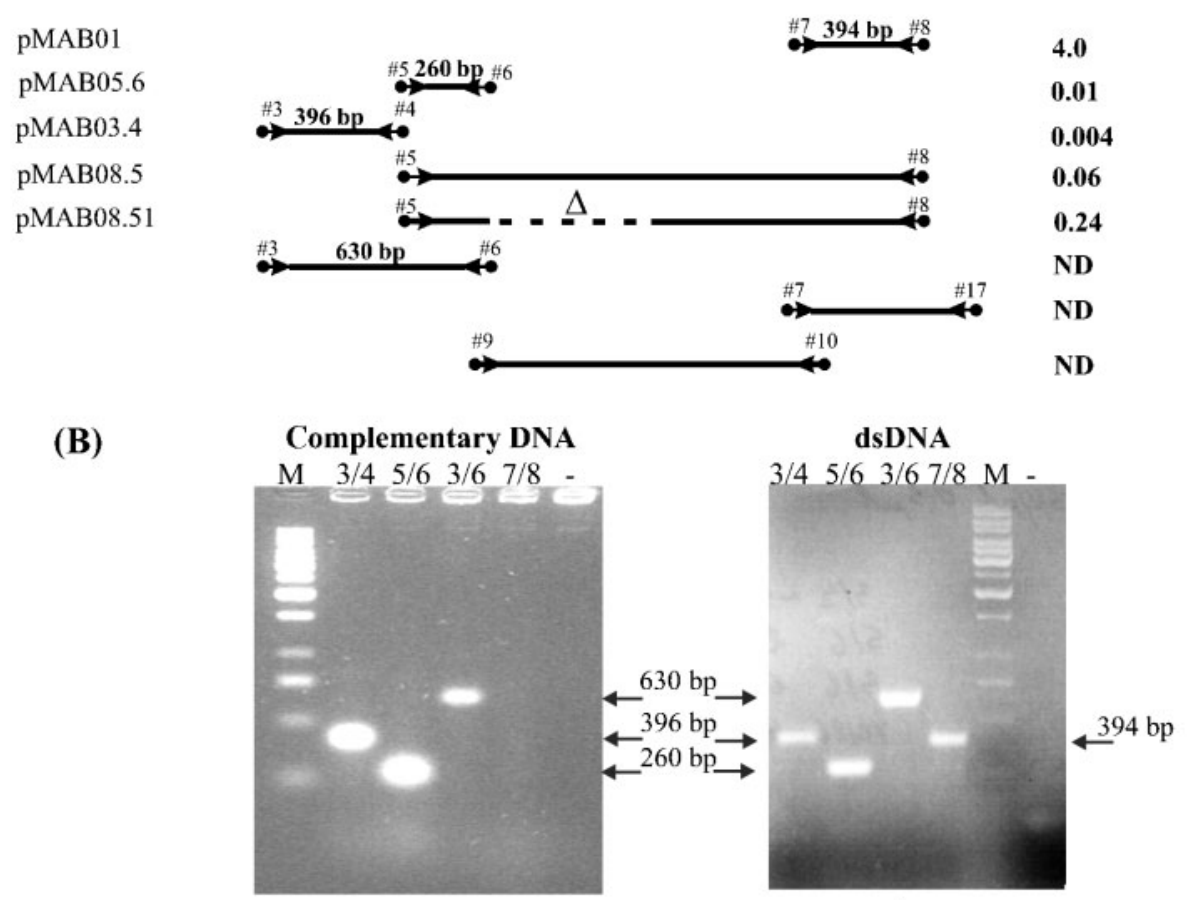

(C)
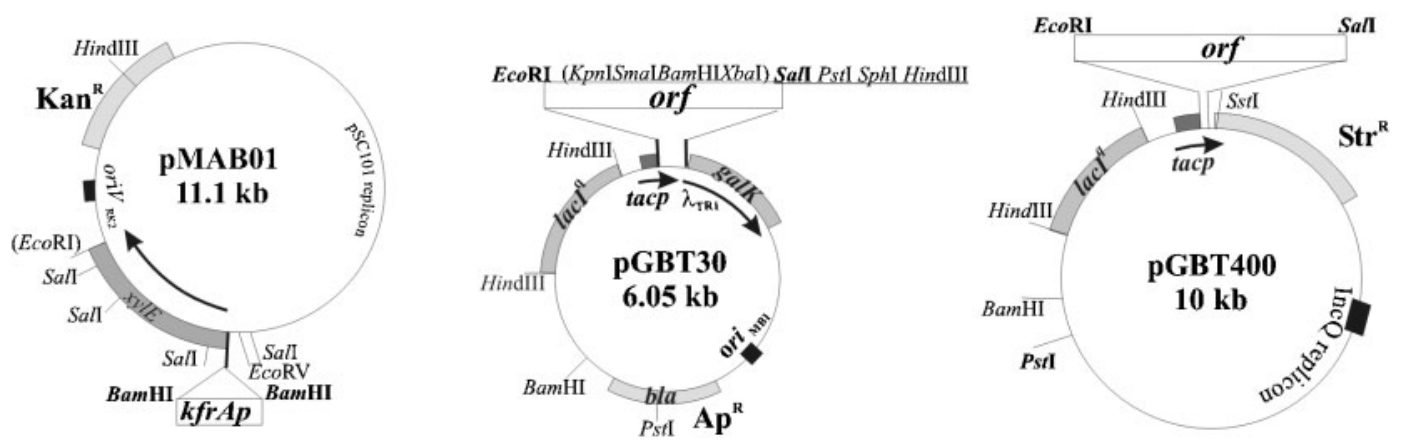

Fig. 2. Transcriptional organization of $k f r A p_{\mathrm{R} 751}$. (A) $k f r A$ region of $\mathrm{R} 751$. Fragments below the diagram were amplified using the indicated primers and R751 Tet ${ }^{R}$ as the template, with the exception of clone \#5\#8 in pMAB08.51, for which the template used in this $\mathrm{PCR}$ reaction was $\mathrm{R} 751 \mathrm{Tet}^{\mathrm{R}} \Delta \mathrm{C}_{2} \mathrm{kfr} A$. The fragments cloned upstream of the $x y / E$ cassette in the promoter-probe vector $\mathrm{pPT} 01$ gave the plasmids listed on the left (for plasmid description see Table 1). The promoter activities detected, expressed as units of catechol oxygenase activity, are summarized in the first column on the right. The second column on the right shows which pairs of primers gave products of the expected size after RT-PCR with cDNA synthesized from RNA from E. coli NEM259(R751Tet ${ }^{\mathrm{R}}$ ), with the use of primer \#1 annealing to the $3^{\prime}$ end of upf54.4. ND, Not determined. (B) RT-PCR products of the kfrA-upf54.8-upf54.4 region obtained from cDNA from cells of strain NEM259 $\left(R 751 \mathrm{Tet}^{\mathrm{R}}\right)$. As positive controls, the same pairs of primers were used with R751 DNA as the template (dsDNA panel). M, 1 kb DNA ladder; -, no template added. (C) Compatible plasmids used in the regulatory studies. $\mathrm{C} 00 \mathrm{~K}^{-}$was first transformed with pMAB01 $(k f r A p-x y / E)$ and then either one, or both, of the pGBT30 and pGBT400 derivatives were introduced to $\mathrm{C} 60 \mathrm{~K}^{-}$(pMAB01). Both expression vectors had exactly the same transcriptional and translational signals to overproduce the regulatory proteins. They differed by copy number, so the experiments with two regulators in trans were done with reciprocal combinations of ORFs, on either medium- or high-copy-number vectors. 
plasmids KorB $\left(\mathrm{O}_{\mathrm{B}}\right)$ (Bignell et al., 1999; Williams et al., 1993; Jagura-Burdzy et al., 1999a; Kostelidou \& Thomas, 2000) and KorA $\left(\mathrm{O}_{\mathrm{A}}\right)$ (Theophilus et al., 1985; JaguraBurdzy \& Thomas, 1995) located in tandem upstream of the predicted -35 region (Supplementary data). Here, $\mathrm{O}_{\mathrm{B}}$ and $\mathrm{O}_{\mathrm{A}}$ are separated by only $3 \mathrm{nt}$ ( $16 \mathrm{nt}$ between their centres of symmetry). While similar close spacing is also observed at $k l c A p_{\mathrm{R} 751}$, previous studies on simultaneous binding and cooperativity of KorA and KorB have been confined to promoters where the centre-to-centre distance between $\mathrm{O}_{\mathrm{B}}$ and $\mathrm{O}_{\mathrm{A}}$ is 32-34 nt. To determine the sensitivity of $k f r A p_{\mathrm{R} 751}$ to KorA and KorB, reporter gene assays were performed with the regulatory genes, inducible by IPTG, provided in trans on compatible plasmids (Fig. 2C). Both KorA and KorB alone showed only two- to fourfold repression but gave about 100-fold repression (Table 3) when present together, giving a cooperativity index of 10, which indicates a 10 -fold higher repression than expected from the product of the repression indices of both proteins individually. Thus, close spacing of $\mathrm{O}_{\mathrm{A}}$ and $\mathrm{O}_{\mathrm{B}}$ did not prevent their cooperative interaction and also did not cause them to interfere with each other. It may be of significance that the centres of symmetry of these operator sequences are actually located $16 \mathrm{bp}$ apart and therefore should be on opposite faces of the DNA helix (Bingle et al., 2005).

We previously showed for RK2 that $k f r A p$ is autoregulated and that the target for $\mathrm{KfrA}_{\mathrm{RK} 2}$ is an operator, $\mathrm{O}_{\mathrm{K}}$, overlapping the -10 region (Jagura-Burdzy \& Thomas, 1992;
Thomas et al., 1990). The long inverted sequence is also present in $k f r A p$ of R751 and this was tentatively named putative $\mathrm{Kfr}_{\mathrm{R} 751}$ operator $\mathrm{O}_{\mathrm{K}}$ (Thorsted et al., 1998). The $k f r A_{\mathrm{R} 751}$ ORF was inserted into pGBT30 and pGBT400 derivatives under tacp control, and the effect of $\mathrm{KfrA}_{\mathrm{R} 751}$ overproduction on the activity of $k f r A p_{\mathrm{R} 751}(k f r A p-x y l E$ transcriptional fusion in pMAB01) was analysed in double transformants. Table 3 shows that when $\mathrm{KfrA}_{\mathrm{R} 751}$ was expressed in trans from tacp, significant repression was observed even without induction by IPTG $(0 \cdot 28 \mathrm{U}$ XylE in the presence of pMAB30.1 in trans to pMAB01 in comparison to $3.55 \mathrm{U}$ in the presence of vector pGBT30 under the same conditions). In contrast, no effect of $\mathrm{Kfr}_{\mathrm{RK} 2}$ on $k f r A p_{\mathrm{R} 751}$ was seen [E. coli $\mathrm{C} 600 \mathrm{~K}(\mathrm{pMAB} 01)(\mathrm{pWS} 131)$, confirming that the $\mathrm{O}_{\mathrm{K}}$ sequences changed autoregulator specificity. The regulatory effects of Upf54.8 (pMAB30.4) and Upf54.4 (pMAB30.5) were tested in the same way, but with negative results (Table 3 ). The presence of Upf54.8 or Upf54.4 did not increase the repression of $k f r A p$ exerted by KfrA from pMAB40.1 (data not shown).

To determine how $\mathrm{Kfr}_{\mathrm{R} 751}$, KorA $\mathrm{R}_{\mathrm{R} 51}$ and KorB $\mathrm{R}_{751}$ might interact at $k f r A p_{\mathrm{R} 751}$, we provided $\operatorname{kor} A$ or $k o r B$ at the same time as $k f r A$. Surprisingly, under uninduced conditions, when either KorA or KorB was present with KfrA, the activity of $k f r A p$ was two- to fourfold higher than when KfrA was present alone (Table 3 ). The effect seemed not to depend on the level of $k o r A / k o r B$ gene dosage versus $k f r A$ gene dosage (tacp- $k f r A$ was expressed either from

Table 3. Effects of different regulators on expression of $k f r A p_{\mathrm{R} 751}$

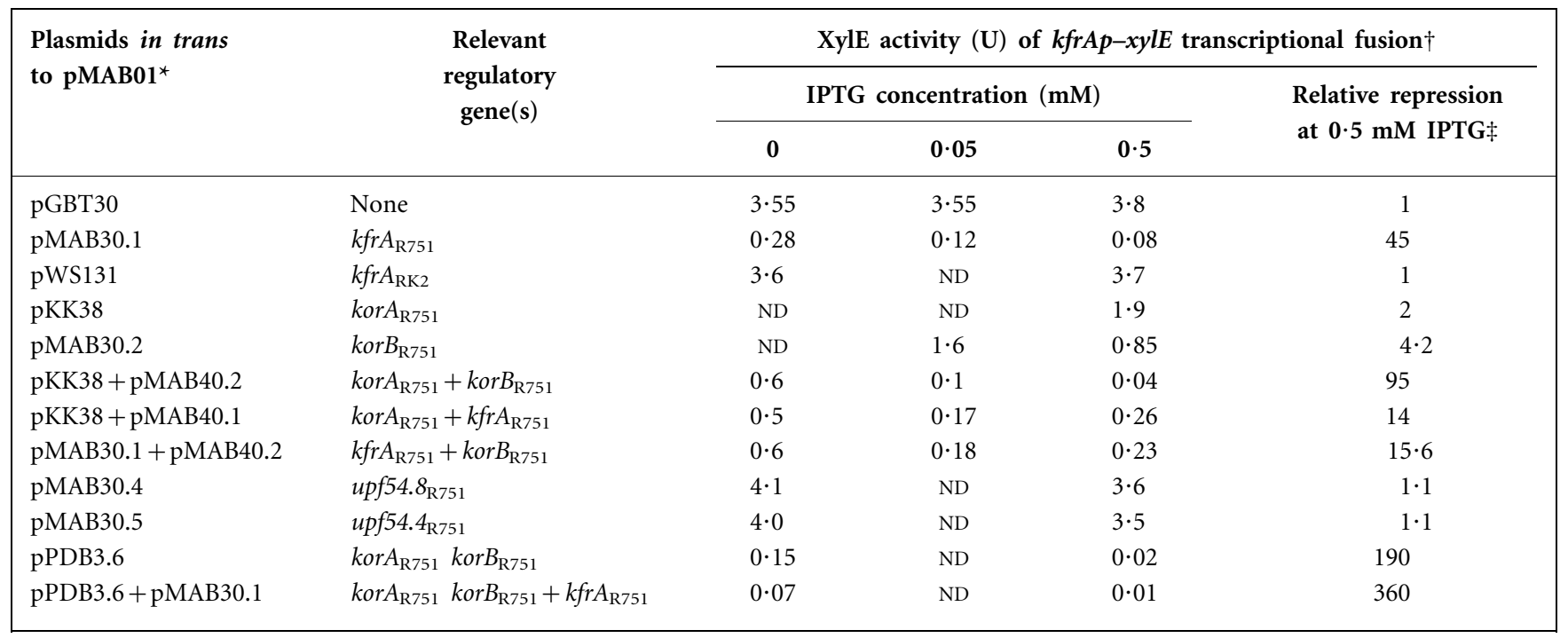

${ }^{\star}$ Regulatory genes were cloned under tacp either on high-copy-number pGBT30 (pMB1 origin) or medium-copy-number derivatives of RSF1010 (IncQ replicon), or pBBR1MCS. All vectors contained the $l a c l^{\mathrm{Q}}$ gene to facilitate tighter transcriptional control. Plasmids were transformed into E. coli $\mathrm{C} 600 \mathrm{~K}^{-}$strain. When two regulators were present in trans no difference was observed in the level of repression related to the gene dosage. $\dagger$ Transcriptional fusion $k f r A p-x y l E$ was present on pMAB01 (derivative of pPT01 vector). The enzymic assays were performed on extracts from exponentially growing cells $\left(\mathrm{OD}_{600} 0 \cdot 4-0 \cdot 6\right)$ after IPTG induction for $2 \cdot 5-3 \mathrm{~h}$ at the indicated concentrations of inducer.

‡Relative repression indicates the XylE activity of strain $\mathrm{C} 60 \mathrm{~K}^{-}$(pMAB01)(pGBT30) grown on $0.5 \mathrm{mM}$ IPTG divided by the XylE activity of the appropriate transformant. 
medium-copy-number plasmid pMAB40.1 or high-copynumber plasmid pMAB30.1). These results suggest some sort of interference between these repressors. Western blotting extracts from the cultures did not indicate any significant fluctuations in the level of KfrA production in the presence or absence of other regulators. The presence of three repressors, KorA, KorB (pPDB3.6) and KfrA (pMAB30.1), together completely shut off expression from $k f r A p$.

\section{Repression by deletion derivatives of KfrA}

From the previous section it can be seen that repression of transcription is a key property of KfrA. The predicted secondary structure of $\mathrm{KfrA}_{\mathrm{R} 751}, 343$ aa, revealed a distinct $\mathrm{N}$-terminal region that might form a globular head linked to a long, coiled-coil, $\alpha$-helical structure (data not shown). No typical DNA binding motifs were detected. This is very similar not only to RK2 KfrA but also to the protein TlpA of pLT2, a protein involved in regulating temperatureresponsive gene expression (Koski et al., 1992; Hurme et al., 1994, 1996, 1997). To determine which parts of KfrA are needed for DNA binding, mutant alleles of $k f r A$ were created with extensive deletions: $\Delta \alpha k f r A$, encoding KfrA, lacking 70 aa between A136 and A207 from the long $\alpha$-helical tail (KfrA $\Delta 137-206) ; \Delta C k f r A$, encoding the $\mathrm{N}$-terminal 136 aa (KfrAl-136); $\Delta C_{2} k f r A$, encoding the N-terminal 186 aa linked in-frame to the C-terminal 20 aa (KfrA $\Delta 187-323)$; and $\Delta N k f r A$, encoding the C-terminal 137 aa (KfrA207-343).

To test the possibility that KfrA might control a temperature-dependent switch, the deletion alleles of $k f r A$ were expressed from tacp in trans to the $k f r A p-x y l E$ reporter plasmid (pMAB01) at 25,37 and $42^{\circ} \mathrm{C}$. At all temperatures, WT KfrA showed very strong repression and this activity appeared to be enhanced even at $42{ }^{\circ} \mathrm{C}$. The C-terminal fragment KfrA207-343 showed no repression at any temperature. At $25^{\circ} \mathrm{C}$, both $\mathrm{KfrAl}-136$ and $\mathrm{KfrA} \Delta 137-206$ were able to repress the $k r f A$ promoter, although KfrAl-136 demonstrated a significant drop in repression compared to wild-type (WT) KfrA or KfrA $\Delta 137-206$. At the higher temperatures, KfrAl-136 lost most of its repressor activity. Interestingly, KfrA $\Delta 137-206$ showed quite clear temperature sensitivity at low levels of induction, with significant levels of repression at $37^{\circ} \mathrm{C}$ but not at $42{ }^{\circ} \mathrm{C}$. However, at higher levels of induction, KfrA $\Delta 137-206$ still caused repression at high temperature and, indeed, was an even more potent transcriptional repressor than WT KfrA, at least at $37^{\circ} \mathrm{C}$ (Table 4). This indicates that the DNA binding domain is in the protein segment amino acids $1-136$, but that the rest of the protein contributes to stabilization of the active form of the protein, so that inactivation can occur at higher temperature in the mutants. The $k f r A$ allele producing KfrA $\Delta 187-323$ with 137 aa removed was also tested (pPDB30.14) and found to have repressor activity comparable to WT KfrA when overproduced (data not shown).

\section{KfrA, Upf54.8 and Upf54.4 interact with each other}

The YTH system was used to test for interactions between $\mathrm{Kfr}_{\mathrm{R} 751}$ and other proteins encoded by the same operon as $\mathrm{KfrA}$, and with proteins encoded by the adjacent central control operon and involved in the active partitioning of

Table 4. Influence of temperature on autorepression ability of KfrA and its truncation products

For key to symbols, see footnotes to Table 3.

\begin{tabular}{|c|c|c|c|c|c|}
\hline \multirow{2}{*}{$\begin{array}{l}\text { Plasmids } \\
\text { in trans to } \\
\text { pMAB01 }^{\star}\end{array}$} & \multirow{2}{*}{$\begin{array}{c}\text { Relevant } \\
\text { KfrA } \\
\text { product }\end{array}$} & \multirow[t]{2}{*}{$\begin{array}{l}\text { IPTG concn } \\
((\mathrm{mM})\end{array}$} & \multicolumn{3}{|c|}{$\begin{array}{l}\text { XylE activity }(\mathrm{U}) \text { of } k f r A p-x y l E \\
\text { transcriptional fusion } \dagger: \text { temperature of growth }\end{array}$} \\
\hline & & & $25^{\circ} \mathrm{C}$ & $37^{\circ} \mathrm{C}$ & $42{ }^{\circ} \mathrm{C}$ \\
\hline \multirow{6}{*}{ pMAB30.1 } & None & 0 & $3 \cdot 55$ & $3 \cdot 55$ & $3 \cdot 60$ \\
\hline & & $0 \cdot 5$ & $3 \cdot 70$ & $3 \cdot 8$ & $3 \cdot 70$ \\
\hline & & Relative repression $\ddagger$ & 1 & 1 & 1 \\
\hline & WT KfrA & 0 & $0 \cdot 20$ & $0 \cdot 28$ & $0 \cdot 04$ \\
\hline & & $0 \cdot 5$ & $0 \cdot 04$ & $0 \cdot 08$ & $0 \cdot 03$ \\
\hline & & Relative repression & 93 & 45 & 123 \\
\hline \multirow[t]{3}{*}{ pMAB30.11 } & KfrA $\Delta 137-206$ & 0 & $0 \cdot 02$ & $0 \cdot 02$ & $3 \cdot 70$ \\
\hline & & $0 \cdot 5$ & $0 \cdot 02$ & $0 \cdot 02$ & $0 \cdot 02$ \\
\hline & & Relative repression & 185 & 190 & 185 \\
\hline \multirow[t]{3}{*}{ pMAB30.12 } & KfrA1-136 & 0 & $4 \cdot 30$ & $3 \cdot 70$ & $3 \cdot 70$ \\
\hline & & $0 \cdot 5$ & $0 \cdot 46$ & $1 \cdot 30$ & $2 \cdot 40$ \\
\hline & & Relative repression & 8 & 3 & $1 \cdot 5$ \\
\hline \multirow[t]{3}{*}{ pMAB30.13 } & KfrA207-343 & 0 & $4 \cdot 00$ & $3 \cdot 60$ & $3 \cdot 9$ \\
\hline & & $0 \cdot 5$ & $3 \cdot 9$ & $3 \cdot 70$ & $3 \cdot 8$ \\
\hline & & Relative repression & 1 & 1 & 1 \\
\hline
\end{tabular}


(A)

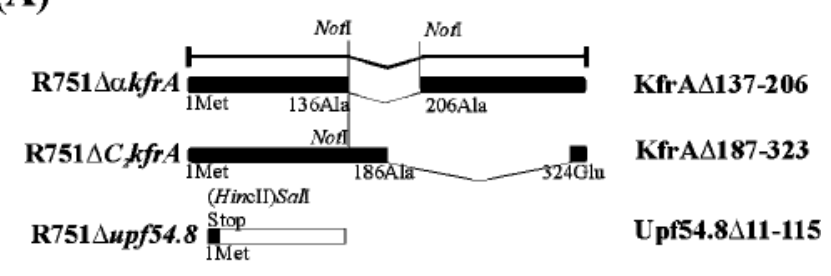

(B)

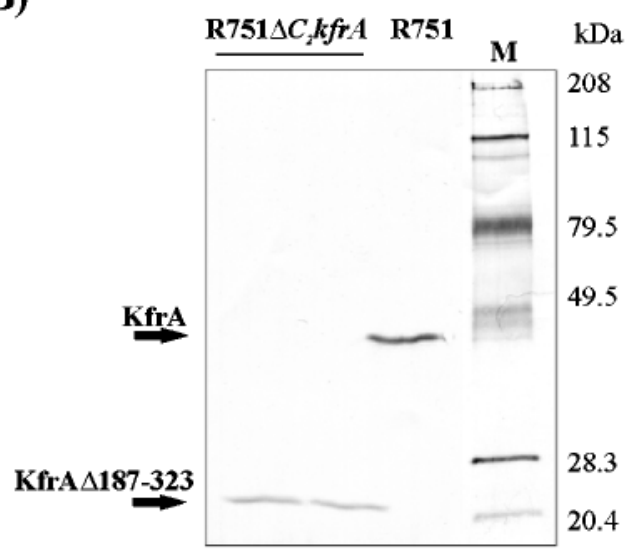

(C)

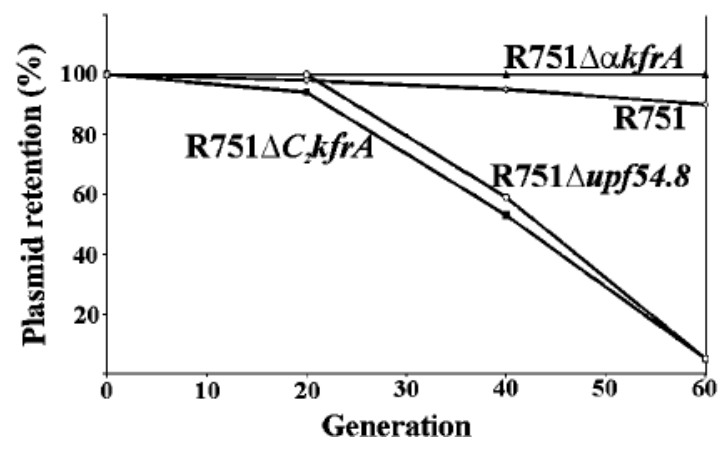

Fig. 3. Stability of R751 mutant derivatives. (A) Schematic representation of mutated $k f r A$ and upf54.8 alleles introduced by reverse genetics into an $\mathrm{R} 751 \mathrm{Tet}^{\mathrm{R}}$ background. The expressed parts of the encoded proteins are marked in black. (B) Western blot of extracts from E. coli NEM259(R751Tet $\left.{ }^{\mathrm{R}} \Delta \mathrm{C}_{2} k f r A\right)$ and NEM259 $\left(R 751\right.$ Tet $\left.^{R}\right)$ with anti-KfrA antibodies. Similar numbers of cells $\left(2 \times 10^{8}\right.$, collected at $\left.\mathrm{OD}_{600} 0.6\right)$ were loaded. Column $M$ shows biotinylated molecular mass markers. (C) Stability data for $\mathrm{R} 751 \mathrm{Tet}^{\mathrm{R}}$ and its three derivatives. Overnight cultures of E. coli NEM259(R751Tet ${ }^{\mathrm{R}}$ or its mutant derivatives), grown on tetracycline, were diluted $10^{5}$-fold and left to grow without selection for $12 \mathrm{~h}$ ( $\sim 20$ generations), and then diluted into fresh medium. At the time of dilution, the appropriate samples were plated on $\mathrm{L}$ agar plates to obtain single colonies, which were subsequently checked for the ability to grow on plates with tetracycline. Plasmid retention was calculated as the percentage of $\mathrm{Tet}^{\mathrm{R}}$ clones in relation to the total number of colonies.
IncP-1 plasmids. To study relevant protein-protein interactions, $k f r A$, incC1, korB, upf54.8 and upf54.4 were cloned into the shuttle vectors pBTM116 and pGAD424 to create translational fusions with the $\mathrm{C}$ termini of LexA and the GAL4 activation domain $\left(\mathrm{GAL}_{\mathrm{AD}}\right)$. S. cerevisiae L40 was used to detect protein-protein interactions on the basis of activation of the lacZ and HIS genes under control of GAL4dependent promoters, with LexA binding sites upstream.

The YTH data demonstrated that KfrA was able to dimerize in vivo. In liquid cultures of double transformants of strain L40(pMAB116.1)(pMAB424.1), a high level (90 U) of $\beta$ galactosidase activity was detected, in comparison with $<0 \cdot 2 \mathrm{U}$ in transformants with control plasmids, suggesting very strong protein-protein interactions. Experiments with glutaraldehyde cross-linking of purified $\mathrm{His}_{6}-\mathrm{KfrA}$ confirmed the ability of $\mathrm{KfrA}_{\mathrm{R} 751}$ to form dimers and other higher-order complexes (data not shown).

No interactions were detected between KfrA and either IncC1 or KorB, which are core components of the active partitioning system encoded by the adjacent operon. These therefore provide negative controls $(<0 \cdot 2 \mathrm{U} \beta$-galactosidase). However, the YTH system did show that there were weak interactions between $\mathrm{KfrA}$ and Upf54.8 (2-5 U $\beta$ galactosidase) but not between KfrA and Upf54.4 (data not shown). Both Upf proteins self-interacted (Upf54.4 dimerization gave rise to $\sim 30 \mathrm{U} \beta$-galactosidase, whereas Upf54.8 was much weaker with $3-5 \mathrm{U})$ and interacted with each other in the YTH system (30-90 U $\beta$-galactosidase, depending on translational fusion). It is therefore possible that although KfrA did not interact with Upf54.4 directly, all three proteins may have formed a complex, with Upf54.8 being the linker between the other two components.

\section{Mutations in KfrA and Upf54.8 lead to plasmid instability}

To establish the role of intact KfrA in R751 biology, mutant $k f r A$ alleles were introduced into the R751Tet ${ }^{\mathrm{R}}$ backbone as described in Methods. In essence, for each mutation, $400 \mathrm{bp}$ arms flanking the mutation were generated by PCR, introduced together into a suicide plasmid, which was then forced to integrate by homologous recombination into R751 (Fig. 3A). Finally excisants were selected and screened by PCR and Western blotting with anti-KfrA antibodies for those that had retained the mutant allele. This was attempted with a total deletion of $k f r A$ as well as two previously characterized deletion alleles, $\Delta \alpha k f r A$ and $\Delta C k f r A$. The procedure worked smoothly for the $\Delta \alpha k f r A$ allele and nine out of 10 clones after the last step had exchanged WT $k f r A$ for the mutation. However, for the $\triangle C k f r A$ allele, only one in 50 analysed clones demonstrated the loss of WT $k f r A$ and, while further analysis indicated the presence of a deletion in $k f r A$, this did not exactly match the allele which was supposed to recombine, producing a larger polypeptide on SDS-PAGE than was expected $\left(M_{\mathrm{r}} 23000\right.$ rather than 17000 estimated from the product of plasmid pMAB30.12) (Fig. 3B). PCR amplification followed by DNA sequencing 


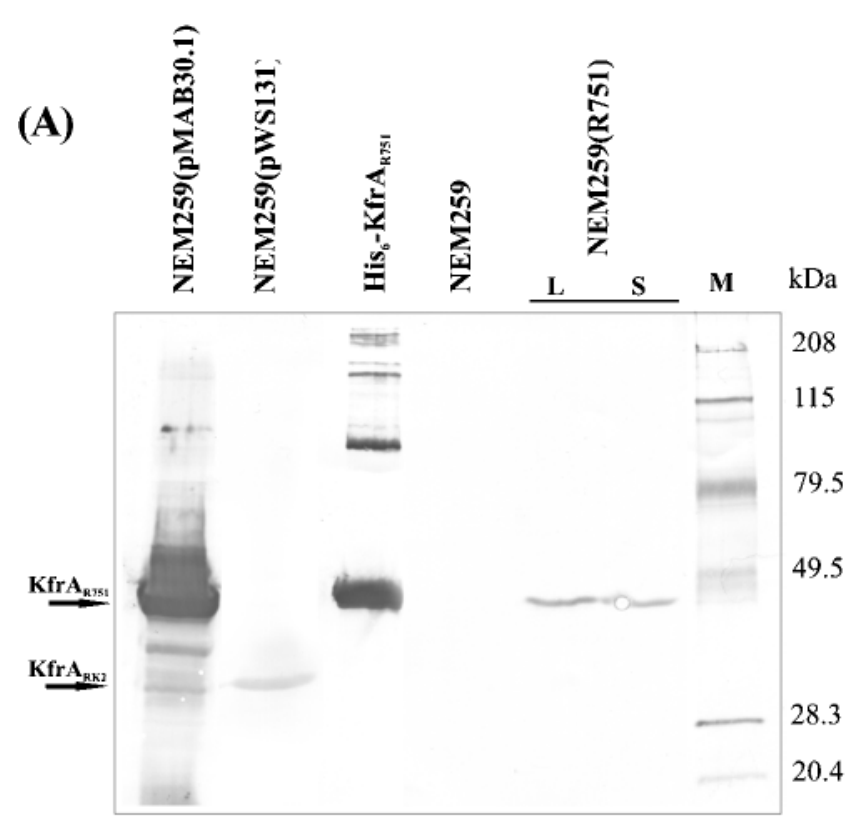

(B)

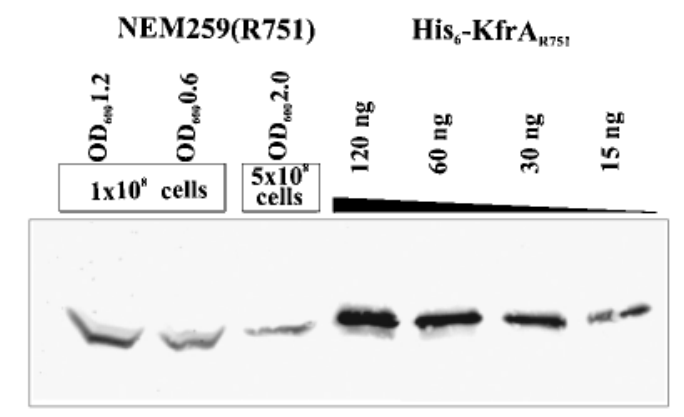

Fig. 4. Intracellular level of $K f r A_{R 751}$. (A) Western blot with anti-KfrA 751 antibodies. Similar numbers of cells from logarithmic cultures $\left(10^{8}\right)$ were loaded on the gel in all tracks, with the exception of track NEM259(R751Tet $\left.{ }^{\mathrm{R}}\right)$, marked S, which corresponds to $2 \times 10^{9}$ cells from the stationary culture (track $L$ represents $10^{8}$ cells of the same strain but from a logarithmic culture). Cells with plasmids overproducing $\mathrm{KfrA}_{\mathrm{R} 751}$ (pMAB30.1) and $\mathrm{Kfr}_{\mathrm{RK} 2}$ (pWS131) were induced for $3 \mathrm{~h}$ with $0.5 \mathrm{mM}$ IPTG. Purified $\mathrm{His}_{6}-\mathrm{KfrA}(1 \cdot 28 \mu \mathrm{g})$ and biotinylated molecular mass standards (track $\mathrm{M}$ ) were also run on this $12 \%$ SDS-polyacrylamide gel. (B) A culture of strain NEM259(R751 Tet $\left.{ }^{R}\right)$ was diluted 100fold and grown on $L$ broth at $37^{\circ} \mathrm{C}$. Growth was monitored by $\mathrm{OD}_{600}$ and c.f.u., and samples were collected, sonicated and analysed by SDS-PAGE with dilutions of purified $\mathrm{His}_{6}-\mathrm{KfrA}$ as standards. This gel is representive of many experiments. The samples from logarithmic cultures correspond to $10^{8}$ cells and that from the stationary culture to $5 \times 10^{8}$ cells. The $O_{600}$ at which the cells were collected is indicated above the tracks. The stationary culture had $\mathrm{OD}_{600} 2 \cdot 0$.

showed that the derivative had a deletion from $187 \mathrm{Q}$ to $323 \mathrm{~L}$, linking the C-terminal 20 aa to the first 186 aa. This derivative was designated $\mathrm{R} 751 \Delta C_{2} k f r A$. The regulatory ability of KfrA $\Delta 187-323$ was tested by cloning the PCR product, under tacp, into pPDB30.14, and was shown to give a similar autorepression effect as WT KfrA (data not shown). The difficulty in obtaining R751 $\triangle C k f r A$ suggested that the allele we tried to introduce, encoding KfrAl-136 with significantly impaired regulatory properties, was somehow disadvantageous for R751. This conclusion is also strengthened by the fact that we were unable to construct an R751 $\Delta k f r A n u l l$ plasmid; none of the 100 derivatives screened had lost $k f r A$ completely.

The two R751Tet ${ }^{\mathrm{R}}$ derivatives that were obtained $\left(\mathrm{R} 751 \mathrm{Tet}{ }^{\mathrm{R}} \Delta \alpha k f r A\right.$ and $\mathrm{R} 751 \mathrm{Tet}^{\mathrm{R}} \Delta C_{2} k f r A$ ) were introduced into E. coli NEM259 and checked for their stability phenotype. The strains were grown for approximately 60 generations without tetracycline selection. Every 20 generations, the cultures were diluted by a factor of $10^{5}$ into fresh medium. The results of this test are presented in Fig. 3(C), demonstrating the loss of R751 $\operatorname{Tet}^{\mathrm{R}} \Delta C_{2} k f r A$, but not R751Tet ${ }^{\mathrm{R}} \Delta \alpha k f r A$. The presence of R751Tet ${ }^{\mathrm{R}} \Delta C_{2} k f r A$ in the host did not inhibit the growth of bacteria more than R751Tet $^{\mathrm{R}}$ (data not shown). Therefore, it seems unlikely that, in the absence of antibiotic selection, the overgrowth of plasmid-free segregants, relative to the cells with R751Tet ${ }^{\mathrm{R}}$ $\Delta C_{2} k f r A$, was the only reason for the observed loss of plasmid stability (especially since neither R751Tet ${ }^{\mathrm{R}}$ itself nor $\mathrm{R} 751 \mathrm{Tet}{ }^{\mathrm{R}} \Delta \alpha k f r A$ demonstrated significant segregation).

The instability of R751 carrying a mutation in $k f r A$ could have been due to a need for KfrA in a complex directly involved in stable inheritance/plasmid survival or an indirect effect due to disrupted regulatory circuits. To distinguish between these possibilities, the production of the truncated KfrA from R751 $\Delta C_{2} k f r A$ was analysed by Western blotting. Standardized samples of bacteria carrying R751 and $\mathrm{R} 751 \Delta C_{2} k f r A$ showed lower production of KfrA $\Delta 187-323$ than KfrA (as expected from regulatory studies) (Fig. 3B), indicating that the level of expression of the $k f r A-u p f 54.8-$ upf54.4 operon was not dramatically disturbed in the $\mathrm{R} 751 \Delta C_{2} k f r A$ mutant, and that plasmid instability was therefore most likely due to a direct role of KfrA.

A mutant allele for upf54.8 was also constructed by introducing a stop codon after the tenth codon into the coding sequence of upf54.8 (pMAB6.41). Using the suicide technique, the wild-type upf54.8 in R751Tet ${ }^{\mathrm{R}}$ was successfully exchanged for the mutated allele at the expected frequency with no problems. The stability test on R751Tet ${ }^{\mathrm{R}} \Delta u p f 54.8$ showed that the mutated plasmid became unstable to a similar extent as with the impaired $k f r A$ allele $\left(\Delta C_{2} k f r A\right)$ (Fig. 3C). The upf54.8-upf54.4 region in RK2 has previously been suggested to be a part of the tra region (Krishnapillai, 1988) and occasionally referred to as traN-traO. The constructed mutant R751Tet ${ }^{\mathrm{R}} \Delta u p f 54.8$ was highly proficient in conjugative transfer between E. coli strains, as well as between E. coli and Pseudomonas aeruginosa. Attempts to construct an upf54.4 deletion allele have not been successful. 
(A)

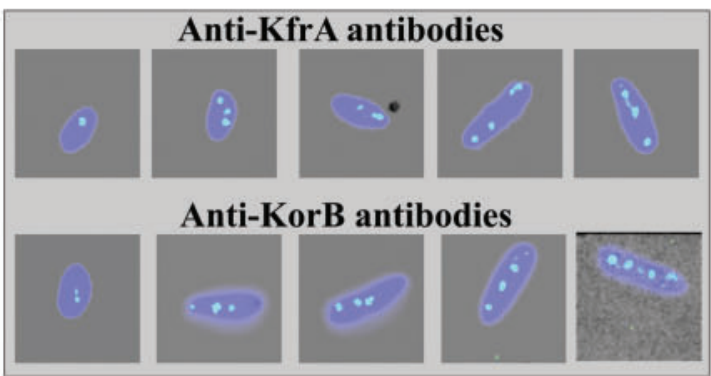

(B)
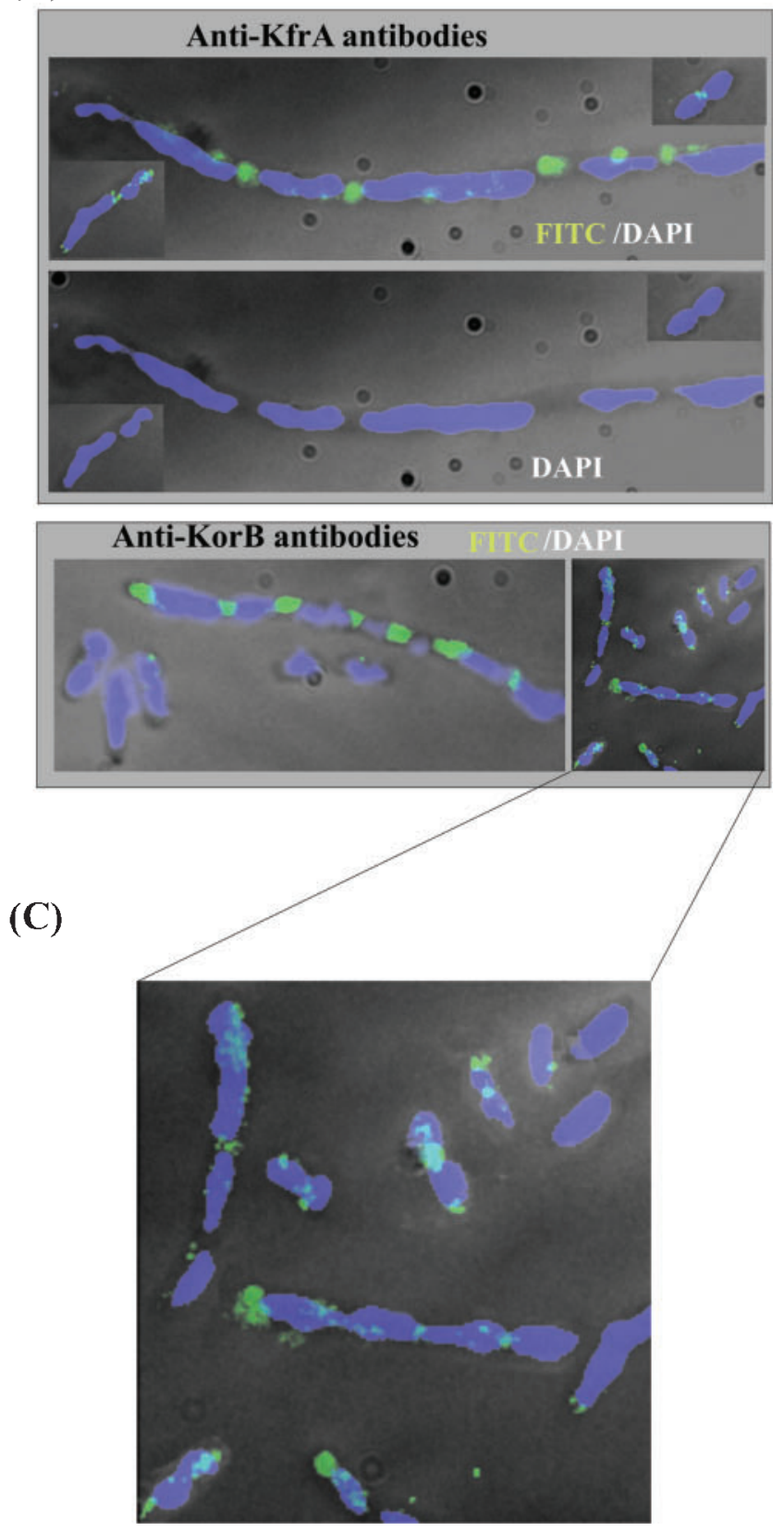

\section{Intracellular concentration of KfrA}

Polyclonal rabbit antibodies raised against KfrA were applied to estimate KfrA concentrations in the cells with plasmid R751. The specificity of anti-KfrA antibodies was tested against $E$. coli extract. A single protein band was detected only when the strain contained R751. There was only very insignificant cross-reactivity between anti- $\mathrm{KfrA}_{\mathrm{R} 751}$ antibodies and $\mathrm{KfrA}_{\mathrm{RK} 2}$. No signal was observed with an extract from E. coli (RK2) (data not shown) and only a very weak signal with highly overproduced $\mathrm{Kfr}_{\mathrm{RK} 2}$ from pWS131 $\left(\right.$ tacp $\left.-k f r A_{\mathrm{RK} 2}\right)$, as demonstrated in Fig. 4(A). Overproduction of $\mathrm{KfrA}_{\mathrm{RK} 2}$ was confirmed by Coomassie staining (data not shown). Thus, the $40 \%$ homology at the primary amino acid sequence level was not sufficient for anti-body cross-reactivity. The purified $\mathrm{Kfr}_{\mathrm{R} 751}$ demonstrated a range of multimers, even without the presence of cross-linking agent. Western blotting was applied to estimate the level of $\mathrm{KfrA}_{\mathrm{R} 751}$ in bacteria from logarithmic and stationary-phase cultures, to determine whether levels were high enough for detection by immunofluorescence, and to compare these levels with those of other regulatory proteins that have already been studied. Previous studies on RK2 proteins (KorA and KorB) showed dependence of the protein level on the stage of culture growth (G. Jagura-Burdzy \& C. M. Thomas, unpublished observations). Extracts from E. coli NEM259(R751Tet ${ }^{\mathrm{R}}$ ) demonstrated that actively growing cells contained up to 7000 monomers of KfrA per cell (the number of cells estimated on the basis of c.f.u.), whereas stationary-phase bacteria contained about 500 monomers of KfrA per cell (Fig. 4B). This drop in number of molecules per cell cannot be explained completely by the smaller size of stationary-phase bacteria, which had decreased approximately twofold, as estimated from the micrographs. This indicates that either production of KfrA was switched off as bacteria approached the end of the exponential phase, or KfrA was degraded. However, no products of KfrA proteolysis were observed, suggesting that there was a transcriptional block in KfrA production in the transition-phase cells. Thus, the fall in KfrA level may have been due to dilution of the protein after production was reduced in bacteria that continued to divide.

Fig. 5. Localization of KfrA in cells with R751 by immunofluorescence. (A) Representative cells of E. coli NEM259(R751Tet ${ }^{R}$ ) stained by DAPI and incubated with the primary anti-KfrA or anti-KorB rabbit antibodies and secondary FITC-conjugated, anti-rabbit antibodies. The top panel shows the cells of strain NEM259(R751 Tet ${ }^{R}$ ) incubated with the primary anti-KfrA $A_{R 751}$ rabbit antibodies. The bottom panel shows the cells from the same culture incubated with the primary anti-KorB $B_{\mathrm{RK} 2}$ rabbit antibodies. (B) Cells of strain NEM259(R751 $\left.\Delta C_{2} k f r A\right)$ were DAPI-stained and incubated with the primary anti-KfrA or antiKorB rabbit antibodies and then FITC-conjugated, anti-rabbit antibodies. Cells were collected from logarithmic culture grown for only $3 \mathrm{~h}$ without selection, so no plasmid loss should have been observed. Representative small and large cells are shown, stained either with DAPI alone or with DAPI and FITC combined. (C) Magnification of part of panel (B). 


\section{KfrA forms foci in the presence of R751}

To determine possible localization of $\mathrm{KfrA}_{\mathrm{R} 751}$ in particular parts of the bacterial cell, and to obtain more information on the defect caused by KfrA $\Delta 187-323\left(\mathrm{R} 751 \Delta C_{2} k f r A\right)$, we used immunofluorescence with anti-KfrA antibodies to visualize $\mathrm{Kfr}_{\mathrm{R} 751}$ protein. In earlier studies, use of anti-KorB antibodies showed that IncP-1 plasmids form one to four foci, dependent on the stage of cell growth, despite the fact that the plasmid copy number per cell is seven to 15 (Bignell et al., 1999; Pogliano et al., 2001). In our experiments, we used anti-KorB and anti-KfrA antibodies. No signals were detected in bacteria without plasmid R751, while very strong and specifically localized foci were observed in bacteria with R751 and the KfrA single binding site (Fig. 5A). Ninety percent of cells contained one to four KfrA foci per cell. A similar distribution of foci was observed with anti-KorB antibodies, suggesting co-localization of KfrA with R751 plasmid clusters.

The visualization experiments were repeated with exponentially growing cultures of $E$. coli NEM259(R751Tet $\left.{ }^{\mathrm{R}} \Delta C_{2} k f r A\right)$. The culture was grown without selection for five to six generations, so the R751 derivative was still expected to be present in most of the bacteria. KorB and KfrA foci were visible in almost all cells, but two different conclusions could be drawn. First, most of the cells were of normal size or only slightly elongated and, in those cells, the KfrA and KorB foci were much smaller, more numerous and localized close to the pole (Fig. 5B, C). Second, there was a significant percentage of long filamentous cells (forming up to $3 \%$ of the population) which had regularly distributed nucleoids and large DNA-free zones between nucleoids filled with KorB/ KfrA/plasmid molecules.

\section{DISCUSSION}

In this paper we provide evidence that three R751 genes, $k f r A, u p f 54.8$ and $u p f 54.4$, form a unit that is transcribed from $k f r A p$ and regulated by KorA, KorB and KfrA. The $k f r A_{\mathrm{RK} 2}$ gene was originally deduced to be monocistronic (Thomas et al., 1990), mainly on the basis of the presence of a predicted mRNA secondary structure downstream of $k f r A$ that may constitute part of a transcriptional terminator, but this picture needs to be reviewed in the light of the studies on $\mathrm{R} 751$. While the low level of transcription into upf54. $8_{\mathrm{R} 751}$ is consistent with there being a transcriptional terminator between $k f r A$ and $u p f 54.8$, the latter gene clearly does not have a strong promoter of its own and transcription from $k f r A$ is able to pass through into the downstream gene. Circumstantial evidence for such operon organization has already been provided by in vitro transcription/translation studies on this region from RK2 as a DNA template: much higher expression of upf54.8 and upf54.4 is observed if $k f r A$ is mutated (D. R. Williams \& C. M. Thomas, unpublished observations). Further work will be necessary in both IncP$1 \alpha$ and $\beta$ systems to establish whether there is any transcriptional termination after $k f r A$ and before $u p f 54.8$ which would result in higher mRNA levels for $k f r A$ relative to the two downstream genes. Our reporter gene assays suggest that any promoter immediately upstream of upf54.8 is very weak, but it is conceivable that even a weak promoter may be significant under some circumstances. Nevertheless, because of the organization, coregulation and physical interaction between the proteins and the phenotypes reported in this paper, we conclude that the upf genes are part of the coregulated plasmid backbone functions of the IncP-1 plasmids, and are probably part of the machinery that ensures the efficient survival of the plasmid as a mobile genetic element. In recognition of this, we suggest that the upf54.8 and upf54.4 genes should be renamed $k f r B$ and $k f r C$, respectively.

A key part of this newly defined operon is the autoregulation by KfrA. The putative target for KfrA is probably an extended inverted repeat overlapping the -10 region of $k f r A p$ (Supplementary data). One could therefore expect $\mathrm{KfrA}_{\mathrm{R} 751}$ to be at least dimeric. This is consistent with the self-association demonstrated using the yeast two-hybrid system and confirmed by chemical cross-linking studies (data not shown). The predicted structure of $\mathrm{KfrA}_{\mathrm{R} 751}$ implicates the whole of the extended $\alpha$-helical, coiled-coil structure in dimerization. The removal of an internal stretch of 70 aa (KfrA $\Delta 136-207)$ or even 137 aa (KfrA $\Delta 187-323)$ from the $\alpha$-helical tail did not impair the autoregulatory properties of $\mathrm{KfrA}_{\mathrm{R} 751}$, at least at $37^{\circ} \mathrm{C}$ (when overproduced), in the dissected $k f r A p-x y l E$ reporter gene assays with tacpwt $k f r A$ or mutants in trans. Nevertheless, deletion of 137 internal aa did have a slight effect in pMAB08.51, which was consistent with it causing fourfold derepression of transcription from $k f r A p$. The N-terminal part of KfrA (KfrAl136) is sufficient for DNA binding and a basal level of repression, but its temperature sensitivity indicates decreased stability relative to full-length KfrA or derivatives containing more of the $\alpha$-helical, coiled-coil domain.

The introduction of the $\Delta \alpha k f r A$ allele (KfrA136-207) into R751 had no effect on plasmid stability. A similar observation has been made previously (Williams et al., 1998) for a short in-frame deletion of $k f r A_{\mathrm{RK} 2}$ in the P7-pMB1 hybrid derivative, which was the basis of the conclusion that $\mathrm{Kfr}_{\mathrm{RK} 2}$ did not play any role in the stability of the test plasmid. Attempts to introduce a null $k f r A$ allele into R751 were unsuccessful. However, the reverse genetic method used to introduce the $k f r A \Delta 137-343$ allele led to formation of a new deletion allele, $k f r A \Delta 186-323$, in R751 $\left(\mathrm{R} 751 \Delta C_{2} k f r A\right)$. The failure to introduce the $k f r A \Delta 137-343$ mutation into the R751 background may be due to either loss of repressor activity (it causes a 30-fold decrease in repression when in excess) or some other function that is essential for plasmid or cellular survival. However, almost all the extra DNA that was present in mutant $\mathrm{R} 751 \Delta C_{2} \mathrm{kfrA}$ was missing from the $\Delta \alpha k f r A$ allele which was successfully introduced into R751. It therefore seems more likely that the failure to recombine $k f r A \Delta 137-343$ into R751 was due to the effect of this deletion on gene expression. As already mentioned, the $k f r A \Delta 187-$ 323 allele, which arose spontaneously in $\mathrm{R} 751 \Delta C_{2} k f r A$, 
seems to increase transcription from $k f r A$ into $k f r B C$ when tested in the promoter-probe vector (pMAB05.81). In the natural context of R751, this mutation does not seem to have a drastic effect on production of truncated KfrA, suggesting that the presence of KorA and KorB, which also repress $k f r A p$, suppresses this slight defect. Nevertheless, the inability to completely inactivate $k f r A$ in R751 implies that, despite $k f r A p$ being subject to repression by KorA and KorB, $\mathrm{KfrA}$ is the lead regulator and is necessary to maintain correct expression levels.

Our estimate of intracellular KfrA concentration is about 7000 monomers per cell, which would give a concentration well in excess of $1 \mu \mathrm{M}$. Fluorescence microscopy indicated that the majority of the these KfrA molecules were present in the same type of plasmid DNA-protein foci as previously identified for KorB of the IncP-1 $\alpha$ plasmids (Bignell et al., 1999). Since there are no additional copies of the putative KfrA binding sequence elsewhere in the genome, other than at $k f r A p$, this implies either protein-protein interaction or presence of multiple, less specific, binding sites. So long as the protein is distributed evenly around the genome, there should still be a small fraction of the promoter unoccupied at any time, thus allowing enough expression to replenish the levels of KfrA. The very weak promoter for $k f r B$ and $k f r C$ may also ensure synthesis of these proteins under steadystate conditions.

The nature of the KfrA-DNA complex formed should be of interest and will be the subject of future work. One of the functions of the KfrABC complex appears to be to aid in the formation of clusters containing multiple copies of the plasmid since, in its absence, the observed foci of KorB bound to $\mathrm{O}_{\mathrm{B}}$ sites in the IncP-1 genome and $\mathrm{KfrA}$ foci split into multiple, smaller signals. This could reflect the fact that individual molecules are no longer sticking together. The structure of KfrA is reminiscent of SMC-like proteins (Soppa, 2001; Rhodes et al., 2004) and, as such, it may be important in linking protein-plasmid DNA complexes together, perhaps helping them to condense into more compact units and this, in turn, may be essential for their correct localization within the bacterial cell.

Thus KfrA may act as a specific plasmid nucleoid organizer that is important for stable inheritance and plasmid survival. This would be consistent with the instability phenotype observed in the R751 $\Delta C_{2} k f r A$ and $\mathrm{R} 751 \Delta k f r B$ mutants constructed, and the importance of $k f r C$ for the plasmid may be reflected by our inability to create a mutation in this gene. The kinetics of R751 $\Delta C_{2} k f r A$ and $\mathrm{R} 751 \Delta k f r B$ plasmid loss may not be typical for defects in the stability determinants. The strains with R751Tet ${ }^{\mathrm{R}} \Delta C_{2} k f r A$ and $\mathrm{R} 751 \mathrm{Tet}^{\mathrm{R}} \Delta k f r B$ do not have an impaired growth rate when compared to the strain with stable $\mathrm{R}^{2} 51 \mathrm{Tet}^{\mathrm{R}}$ and the $\mathrm{R}^{\mathrm{R}} 751 \mathrm{Tet}^{\mathrm{R}} \Delta \alpha k f r A$ derivative. The $\Delta C_{2} k f r A$ mutation does not seem to disturb significantly the level of expression of the $k f r A$ operon, although we cannot exclude an effect on the general level of expression of other genes, as it leads to the defect in plasmid clustering and, putatively, DNA condensation.
Introduction of the $k f r A$ allele on a medium-copy plasmid in trans to E. coli $\mathrm{NEM}\left(\mathrm{R} 751 \mathrm{Tet}^{\mathrm{R}}\right)$ led to $90 \%$ loss of R751 after 10 generations (data not shown), so the attempt to complement the $\Delta C_{2} k f r A$ mutation by supplying extra WT $\mathrm{KfrA}$ was declined. Previous studies suggest that the IncP-1 active partitioning system requires additional functions to work efficiently (Thorsted et al., 1998). It is conceivable that $\mathrm{KfrABC}$ could be part of this apparatus, but we were unable to demonstrate any direct interactions between $\mathrm{KfrA}$ and either KorB or IncC. The negative results may reflect a real lack of protein-protein interactions, improper folding of the hybrid proteins, or interactions taking place only under certain conditions, such as DNA binding or in the presence of other proteins within a multi-protein complex. On the other hand, we were able to demonstrate interactions between $\mathrm{KfrA}$ and $\mathrm{KfrB}$ and between KfrB and KfrC. This, therefore, defines additional likely components of the plasmid foci. A challenge for the future will be to isolate those complexes still bound to DNA and to determine which other host- or plasmid-encoded proteins are present. A catalogue of such proteins is probably essential before one attempts to predict a role for such complexes, because a prediction based on an incomplete picture is likely to be unreliable.

All the systems in which KfrA-like proteins are encoded also carry a type 1 ParAB active partitioning system, according to the classification of Gerdes et al. (2000b). The localization of the putative $k f r A s$ is close to either rep/oriV regions or partitioning/stabilization cassettes. If the IncP-1 system is a good model, then we might expect to be able to identify homologues/analogues of $\mathrm{KfrB}$ and $\mathrm{KfrC}$. Examination of ORFs next to $k f r A$ homologues in different plasmids indicates that some of these may be part of the same transcriptional units as $k f r A s$. Further biochemical characterization of the products of $k f r A, k f r B$ and $k f r C$ of IncP-1 plasmids is under way and may shed some light on the functions of these proteins in plasmid stability.

\section{ACKNOWLEDGEMENTS}

We thank Wei Zeng for instruction in fluorescence microscopy and technical assistance. This work was funded by PAS grant 6PO4A 07019 and, in part, by an EMBO short-term fellowship awarded to M. A. and UK BBSRC grant 6/G10277.

\section{REFERENCES}

Arnold, F. H. (1991). Metal-affinity separations: a new dimension in protein processing. Biotechnology 9, 151-156.

Bignell, C. R. \& Thomas, C. M. (2001). The bacterial ParA-ParB partitioning proteins. J Biotechnol 91, 1-34.

Bignell, C. R., Haines, A. S., Khare, D. \& Thomas, C. M. (1999). Effect of growth rate and incC mutation on symmetric plasmid distribution by the IncP-1 partitioning apparatus. Mol Microbiol 34, 205-216.

Bingle, L. E., Macartney, D. P., Fantozzi, A., Manzoor, S. E. \& Thomas, C. M. (2005). Flexibility in repression and cooperativity by KorB of broad host range IncP-1 plasmid RK2. J Mol Biol 349, 302-316. 
Birnboim, H. C. \& Doly, J. (1979). A rapid alkaline extraction procedure for screening recombinant plasmid DNA. Nucleic Acids Res 7, 1513-1523

Blakely, G., May, G., McCulloch, R., Arciszewska, L. K., Burke, M., Lovett, S. T. \& Sherratt, D. J. (1993). Two related recombinases are required for site-specific recombination at dif and cer in E. coli K12. Cell 75, 351-361.

Bradford, M. M. (1976). A rapid and sensitive method for the quantitation of microgram quantities of protein utilizing the principle of protein-dye binding. Anal Biochem 72, 248-254.

Burland, V., Shao, Y., Perna, N. T., Plunkett, G., Sofia, H. J. \& Blattner, F. R. (1998). The complete DNA sequence and analysis of the large virulence plasmid of Escherichia coli O157:H7. Nucleic Acids Res 26, 4196-4204.

Chen, D. C., Yang, B. C. \& Kuo, T. T. (1992). One-step transformation of yeast in stationary phase. Curr Genet 21, 83-84.

Close, S. M. \& Kado, C. I. (1992). A gene near the plasmid pSa origin of replication encodes a nuclease. Mol Microbiol 6, 521-527.

Easter, C. L., Schwab, H. \& Helinski, D. R. (1998). Role of the parCBA operon of the broad-host-range plasmid RK2 in stable plasmid maintenance. J Bacteriol 180, 6023-6030.

El-Sayed, A. K., Hothersall, J. \& Thomas, C. M. (2001). Quorumsensing-dependent regulation of biosynthesis of the polyketide antibiotic mupirocin in Pseudomonas fluorescens NCIMB 10586. Microbiology 147, 2127-2139.

Fields, S. \& Song, O. (1989). A novel genetic system to detect protein-protein interactions. Nature 340, 245-246.

Gerdes, K., Ayora, S., Canosa, I. \& 10 other authors (2000a). Plasmid maintenance systems. In Horizontal Gene Pool. Bacterial Plasmids and Gene Spread, pp. 49-85. Edited by C. M. Thomas. Amsterdam: Harwood Academic Publishers.

Gerdes, K., Moller-Jensen, J. \& Bugge Jensen, R. (2000b). Plasmid and chromosome partitioning: surprises from phylogeny. Mol Microbiol 37, 455-466.

Haneda, T., Okada, N., Nakazawa, N., Kawakami, T. \& Danbara, H. (2001). Complete DNA sequence and comparative analysis of the 50-kilobase virulence plasmid of Salmonella enterica serovar Choleraesuis. Infect Immun 69, 2612-2620.

Hirano, T. (1998). SMC protein complexes and higher-order chromosome dynamics. Curr Opin Cell Biol 10, 317-322.

Hurme, R., Namork, E., Nurmiaho-Lassila, E. L. \& Rhen, M. (1994). Intermediate filament-like network formed in vitro by a bacterial coiled coil protein. J Biol Chem 269, 10675-10682.

Hurme, R., Berndt, K. D., Namork, E. \& Rhen, M. (1996). DNA binding exerted by a bacterial gene regulator with an extensive coiled-coil domain. J Biol Chem 271, 12626-12631.

Hurme, R., Berndt, K. D., Normark, S. J. \& Rhen, M. (1997). A proteinaceous gene regulatory thermometer in Salmonella. Cell 90, 55-64.

Jagura-Burdzy, G. \& Thomas, C. M. (1992). kfrA gene of broad host range plasmid RK2 encodes a novel DNA-binding protein. J Mol Biol 225, 651-660.

Jagura-Burdzy, G. \& Thomas, C. M. (1994). KorA protein of promiscuous plasmid RK2 controls a transcriptional switch between divergent operons for plasmid replication and conjugative transfer. Proc Natl Acad Sci U S A 91, 10571-10575.

Jagura-Burdzy, G. \& Thomas, C. M. (1995). Purification of KorA protein from broad host range plasmid RK2: definition of a hierarchy of KorA operators. J Mol Biol 253, 39-50.

Jagura-Burdzy, G., Ibbotson, J. P. \& Thomas, C. M. (1991). The korF region of broad-host-range plasmid RK2 encodes two polypeptides with transcriptional repressor activity. J Bacteriol 173, 826-833.
Jagura-Burdzy, G., Macartney, D. P., Zatyka, M., Cunliffe, L., Cooke, G. D., Huggins, C., Khanim, F. \& Thomas, C. M. (1999a). Repression at a distance by the global regulator KorB of promiscuous IncP plasmids. Mol Microbiol 32, 519-532.

Jagura-Burdzy, G., Kostelidou, K., Pole, J., Khare, D., Jones, A., Williams, D. R. \& Thomas, C. M. (1999b). IncC of broad-host-range plasmid RK2 modulates KorB transcriptional repressor activity in vivo and operator binding in vitro. J Bacteriol 181, 2807-2815.

Johnson, E. P., Strom, A. R. \& Helinski, D. R. (1996). Plasmid RK2 toxin protein ParE: purification and interaction with the ParD antitoxin protein. J Bacteriol 178, 1420-1429.

Kahn, M. R., Kolter, R., Thomas, C. M., Figurski, D., Meyer, R., Remault, E. \& Helinski, D. R. (1979). Plasmid cloning vehicles derived from plasmids ColE1, F, R6K and RK2. Methods Enzymol 68, 268-280.

Koski, P., Saarilahti, H., Sukupolvi, S., Taira, S., Riikonen, P., Osterlund, K., Hurme, R. \& Rhen, M. (1992). A new alpha-helical coiled coil protein encoded by the Salmonella typhimurium virulence plasmid. J Biol Chem 267, 12258-12265.

Kostelidou, K. \& Thomas, C. M. (2000). The hierarchy of KorB binding at its 12 binding sites on the broad-host-range plasmid RK2 and modulation of this binding by IncC1 protein. J Mol Biol 295, 411-422.

Kostelidou, K. \& Thomas, C. M. (2002). DNA recognition by the KorA proteins of IncP-1 plasmids RK2 and R751. Biochim Biophys Acta 1576, 110-118.

Kovach, M. E., Elzer, P. H., Hill, D. S., Robertson, G. T., Farris, M. A., Roop, R. M., II \& Peterson, K. M. (1995). Four new derivatives of the broad-host-range cloning vector pBBR1MCS, carrying different antibiotic- resistance cassettes. Gene 166, 175-176.

Krishnapillai, V. (1988). Molecular genetic analysis of bacterial plasmid promiscuity. FEMS Microbiol Rev 4, 223-237.

Kwong, S. M., Yeo, C. C., Chuah, D. \& Poh, C. L. (1998). Sequence analysis of plasmid pRA2 from Pseudomonas alcaligenes NCIB 9867 (P25X) reveals a novel replication region. FEMS Microbiol Lett 158, 159-165.

Kwong, S. M., Yeo, C. C., Suwanto, A. \& Poh, C. L. (2000), Characterization of the endogenous plasmid from Pseudomonas alcaligenes NCIB 9867: DNA sequence and mechanism of transfer. J Bacteriol 182, 81-90.

Laemmli, U. K. (1970). Cleavage of structural proteins during the assembly of the head of bacteriophage T4. Nature 227, 680-685.

Lukaszewicz, M., Kostelidou, K., Bartosik, A. A., Cooke, G. D., Thomas, C. M. \& Jagura-Burdzy, G. (2002). Functional dissection of the ParB homologue (KorB) from IncP-1 plasmid RK2. Nucleic Acids Res 30, 1046-1055.

Ma, J. \& Ptashne, M. (1987). A new class of yeast transcriptional activators. Cell 51, 113-119.

Macartney, D. P., Williams, D. R., Stafford, T. \& Thomas, C. M. (1997). Divergence and conservation of the partitioning and global regulation functions in the central control region of the IncP plasmids RK2 and R751. Microbiology 143, 2167-2177.

McKenney, K., Shimatake, H., Court, D., Schmeissner, U., Brady, C. \& Rosenberg, M. (1981). A system to study promoter and terminator signals recognized by Escherichia coli RNA polymerase. Gen Amplific Anal 2, 383-415.

Motallebi-Veshareh, M., Rouch, D. A. \& Thomas, C. M. (1990). A family of ATPases involved in active partitioning of diverse bacterial plasmids. Mol Microbiol 4, 1455-1463.

Mullis, K., Faloona, F., Scharf, S., Saiki, R., Horn, G. \& Erlich, H. (1986). Specific enzymatic amplification of DNA in vitro: the polymerase chain reaction. Cold Spring Harbor Symp Quant Biol 51, 263-273. 
Pansegrau, W., Lanka, E., Barth, P. T. \& 7 other authors (1994). Complete nucleotide sequence of Birmingham IncP alpha plasmids. Compilation and comparative analysis. J Mol Biol 239, 623-663.

Pogliano, J., Ho, T. Q., Zhong, Z. \& Helinski, D. R. (2001). Multicopy plasmids are clustered and localized in Escherichia coli. Proc Natl Acad Sci U S A 98, 4486-4491.

Reznekov, O., Alper, S. \& Losick, R. (1996). Subcellular localization of proteins governing the proteolytic activation of a developmental transcription factor in Bacillus subtilis. Genes Cells 1, 529-542.

Rhodes, G., Parkhill, J., Bird, C., Ambrose, K., Jones, M. C., Huys, G., Swing, J. \& Pickup, R. W. (2004). Complete nucleotide sequence of the conjugative tetracycline resistance plasmid pFBAOT6, a member of a group of IncU plasmids with global ubiquity. App Envir Microb 70, 7497-7510.

Roberts, R. C. \& Helinski, D. R. (1992). Definition of a minimal plasmid stabilization system from the broad-host-range plasmid RK2. J Bacteriol 174, 8119-8132.

Roberts, R. C., Spangler, C. \& Helinski, D. R. (1993). Characteristics and significance of DNA binding activity of plasmid stabilization protein ParD from the broad host-range plasmid RK2. J Biol Chem 268, 27109-27117.

Sambrook, J., Fritsch, E. F. \& Maniatis, T. (1989). Molecular Cloning: a Laboratory Manual, 2nd edn. Cold Spring Harbor, NY: Cold Spring Harbor Laboratory.

Soppa, J. (2001). Prokaryotic structural maintenance of chromosomes (SMC) proteins: distribution, phylogeny, and comparison with MukBs and additional prokaryotic and eukaryotic coiled-coil proteins. Gene 278, 253-264.

Studier, F. W. \& Moffatt, B. A. (1981). Use of bacteriophage T7 RNA polymerase to direct selective high-level expression of cloned genes. J Mol Biol 189, 113-130.

Summers, D. K. \& Sherratt, D. J. (1984). Multimerization of high copy number plasmids causes instability: CoIE1 encodes a determinant essential for plasmid monomerization and stability. Cell 36, 1097-1103.

Tauch, A., Schneiker, S., Selbitschka, W. \& 13 other authors (2002). The complete nucleotide sequence and environmental distribution of the cryptic, conjugative, broad-host-range plasmid pIPO2 isolated from bacteria of the wheat rhizosphere. Microbiology 148, 1637-1653.

Theophilus, B. D. M., Cross, M. A., Smith, C. A. \& Thomas, C. M. (1985). Regulation of the $\operatorname{trf} A$ and $\operatorname{trf} B$ promoters of broad host range plasmid RK2: identification of sequences essential for regulation by $\operatorname{trfB/korA/korD.~Nucleic~Acids~Res~13,~8129-8142.~}$

Thomas, C. M., Theophilus, B. D., Johnston, L., Jagura-Burdzy, G., Schilf, W., Lurz, R. \& Lanka, E. (1990). Identification of a seventh operon on plasmid RK2 regulated by the korA gene product. Gene 89, 29-35.

Thorsted, P. B., Macartney, D. P., Akhtar, P. \& 9 other authors (1998). Complete sequence of the IncPbeta plasmid R751: implications for evolution and organisation of the IncP backbone. J Mol Biol 282, 969-990.

Williams, D. R. \& Thomas, C. M. (1992). Active partitioning of bacterial plasmids. J Gen Microbiol 138, 1-16.

Williams, D. R., Motallebi-Veshareh, M. \& Thomas, C. M. (1993). Multifunctional repressor KorB can block transcription by preventing isomerization of RNA polymerase-promoter complexes. Nucleic Acids Res 21, 1141-1148.

Williams, D. R., Macartney, D. P. \& Thomas, C. M. (1998). The partitioning activity of the RK2 central control region requires only inc $C$, korB and KorB-binding site $\mathrm{O}(\mathrm{B})_{3}$ but other KorB-binding sites form destabilizing complexes in the absence of $\mathrm{O}(\mathrm{B})_{3}$. Microbiology 144, 3369-3378.

Yanisch-Perron, C., Vieira, J. \& Messing, J. (1985). Improved M13 phage cloning vectors and host strains: nucleotide sequences of the M13mp18 and pUC19 vectors. Gene 33, 103-119.

Zielenkiewicz, U. \& Ceglowski, P. (2001). Mechanisms of plasmid stable maintenance with special focus on plasmid addiction systems. Acta Biochim Pol 48, 1003-1023.

Zukowski, M. M., Gaffney, D. F., Speck, D., Kauffman, M., Findeli, A., Wisecup, A. \& Lecoq, J. P. (1983). Chromogenic identification of genetic regulatory signals in Bacillus subtilis based on expression of a cloned Pseudomonas gene. Proc Natl Acad Sci U S A 80, 1101-1105. 